\title{
Loss of Innocence: Albert Moll, Sigmund Freud and the Invention of Childhood Sexuality Around 1900
}

\author{
LUTZ D.H. SAUERTEIG* \\ Centre for the History of Medicine and Disease, Wolfson Research Institute, Queen's Campus, \\ Durham University, Stockton-on-Tees TS17 6BH, UK
}

\begin{abstract}
This paper analyses how, prior to the work of Sigmund Freud, an understanding of infant and childhood sexuality emerged during the nineteenth century. Key contributors to the debate were Albert Moll, Max Dessoir and others, as fin-de-siècle artists and writers celebrated a sexualised image of the child. By the beginning of the twentieth century, most paediatricians, sexologists, psychologists, psychiatrists, psychoanalysts and pedagogues agreed that sexuality formed part of a child's 'normal' development. This paper argues that the main disagreements in discourses about childhood sexuality related to different interpretations of children's sexual experiences. On the one hand stood an explanation that argued for a homology between children's and adults' sexual experiences, on the other hand was an understanding that suggested that adults and children had distinct and different experiences. Whereas the homological interpretation was favoured by the majority of commentators, including Moll, Freud, and to some extent also by C.G. Jung, the heterological interpretation was supported by a minority, including childhood psychologist Charlotte Bühler.
\end{abstract}

Keywords: Childhood Sexuality, Child-Woman, Psychology, Psychoanalysis, Sexology, Charlotte Bühler, Max Dessoir, Havelock Ellis, Wilhelm Fließ, Sigmund Freud, Carl Gustav Jung, Karl Kraus, Sámuel Lindner, Albert Moll, Egon Schiele, Wilhelm Stekel, William Stern, Fritz Wittels

\section{Introduction}

Around 1900, a heightened interest in the sexuality of children emerged. Whereas previously sexual activities of children, such as masturbation, had been understood as pathological, this began to change as infant and childhood sexuality were conceptualised

\footnotetext{
*Email address for correspondence: 1.d.sauerteig@durham.ac.uk
}

I am very grateful to Rosemary Elliot, Hans-Georg Hofer, James Kennaway, to our research associate, Sebastian Pranghofer, and to the two anonymous reviewers whose comments and critique helped me to sharpen my argument. I am also indebted to questions and comments from participants in research seminars at the universities of Warwick, Leeds and Oxford, UCL and the Institute for Historical Research, London, where I had the opportunity to present and discuss different versions of this paper. Great thanks go to the Wellcome Trust for its continuous support of my research and to Mike Laycock for his editorial assistance. Any flaws are my own responsibility. 
as part of a child's normal development. ${ }^{1}$ Key participants in the debate defining infant and childhood sexuality included Albert Moll (1862-1939), Sigmund Freud (1856-1939), Carl Gustav Jung (1875-1961), William Stern (1871-1938) and Charlotte Bühler (1893-1974). The historiography to date has mainly centred on Freud, who is perceived as the one who introduced the notion of sexuality being central to, and normal in, infancy and childhood. However, Freud's psychoanalytical thinking was part of a more general contemporary discussion about sexuality in childhood that began in the second half of the nineteenth century and flourished around 1900. Numerous researchers, including physicians, paediatricians, psychologists, psychiatrists, psychoanalysts, educationists, philosophers and sexologists as well as journalists, writers and artists contributed to this discussion across central Europe. Indeed, in 1973, the historian Stephen Kern claimed that the 'discovery of childhood sexuality' was already very much 'in the air' around 1900 and not 'the sudden inspiration of one man', that is, Freud. ${ }^{2}$ This had already been noticed a few years earlier by psychiatrist Henri Ellenberger in his pioneering encyclopaedic history of psychiatry and, about ten years later, again acknowledged by educationalist Sterling Fishman in a brief overview of the history of childhood sexuality. ${ }^{3}$ Despite the recognition that Freud's work was neither revolutionary nor unique, alternative approaches to child sexuality, such as those by Moll, Jung, Stern and Bühler, have largely been neglected. This is perhaps because Freud's contribution is perceived as the most influential, shaping the debates at the beginning of the twentieth century. ${ }^{4}$

Within the Freud historiography, attention has focused on Freud's concept of childhood sexuality and the ways in which his thinking was informed. Through a meticulous investigation of Freud's published and unpublished papers, including annotated books from his library, Frank Sulloway demonstrated how Freud was influenced by his discussions with his long-term correspondent and friend, the Berlin physician Wilhelm Fließ (1858-1928), and probably also by his reading of the work of his opponent and enemy, the Berlin sexologist and psychologist Albert Moll. ${ }^{5}$ Crucially, Sulloway shows how, in 1905, Freud concluded in his Drei Abhandlungen zur Sexualtheorie [Three Essays on the Theory of Sexuality] that the sexual activities of infants and children were part of their normal development, a point which contradicted previous thinking about the pathological nature of childhood sexuality. ${ }^{6}$ While recognising the value of Sulloway's work, my paper provides a new interpretation of Moll's work and its relationship to Freud in the intellectual context of the time, suggesting that Moll came up with a theoretical

\footnotetext{
${ }^{1}$ Contemporary authors hardly ever provided clear definitions of the age range for infants and children. In this paper, I will use 'infants' for children during their first years of life and 'children' for older children up to adolescence.

${ }^{2}$ Stephen Kern, 'Freud and the Discovery of Child Sexuality', History of Childhood Quarterly, 1 (1973), 117-41: 117.

${ }^{3}$ Henri Ellenberger, The Discovery of the Unconscious: The History and Evolution of Dynamic Psychiatry (New York: Basic Books, 1970), 295-6, 504; Sterling Fishman, 'The History of Childhood Sexuality', Journal of Contemporary History, 17 (1982), 269-83.

${ }^{4}$ Fishman, op. cit. (note 3); also K. Codell Carter, 'Infantile Hysteria and Infantile Sexuality in Late NineteenthCentury German-Language Medical Literature', Medical History, 27 (1983), 186-96.

${ }^{5}$ Frank Sulloway, Freud, Biologist of the Mind: Beyond the Psychoanalytic Legend (New York: Basic Books, 1979), the revised German translation, idem, Freud, Biologe der Seele: Jenseits der psychoanalytischen Legende, Hans-Horst Henschen (trans.) (Cologne: Hohenheim, 1982). I am using here the revised German edition.

${ }^{6}$ Sigmund Freud, 'Drei Abhandlungen zur Sexualtheorie (1905, 1910, 1925)', in idem, Studienausgabe, 10 vols and supplement, Alexander Mitscherlich, Angela Richards and James Strachey (eds), Vol. 5 (Frankfurt: Fischer, 2000), 37-145, also in Sigmund Freud, Gesammelte Werke: Chronologisch geordnet, Vol. 5 (London: Imago, 1942), 27-145.
} 
interpretation of childhood sexuality which pre-dated Freud's conceptualisation of normal childhood sexuality. This accords with Arnold Davidson's assertion 'that Moll discovered infantile sexuality years before Freud', although Davidson regarded the question of priority as inadequate to understand Freud's place in history. ${ }^{7}$ My paper explores the antagonism and conflict between Moll and Freud which shaped their respective intellectual developments and offers some suggestions as to why Moll was eventually eclipsed by Freud.

The tensions between Moll and Freud are, however, only one instalment in a much longer history of changing understanding of childhood sexuality which can be mapped onto the social and cultural history of childhood. In contrast to the narratives provided by pioneers in the history of childhood such as Philip Ariès, ${ }^{8}$ historians now recognise that childhood as a concept has existed throughout history. ${ }^{9}$ Whereas some historians of the modern period see concepts of childhood and adolescence and perceptions of sexual feelings only fully emerging at the start of the twentieth century, ${ }^{10}$ other historians, in particular of the early modern period, suggest a much greater awareness of children's sexual activities than has previously been recognised. ${ }^{11}$ The question this longer historical perspective raises is why the interest in childhood sexuality heightened around 1900. Thus, my paper also explores the extent to which the specific cultural context shaped debates, given the backdrop of fin-de-siècle Vienna and Berlin highlighted by Sander Gilman in his contextualisation of Freud's Three Essays. ${ }^{12}$

\footnotetext{
${ }^{7}$ Arnold Davidson, 'How to do the History of Psychoanalysis: A Reading of Freud's Three Essays on the Theory of Sexuality', Critical Inquiry, 13 (1986/7), 252-77: 257.

${ }^{8}$ Philip Ariès, Centuries of Childhood (London: Cape, 1962) (French original 1960).

${ }^{9}$ Miriam Gebhardt, Die Angst vor dem kindlichen Tyrannen: Eine Geschichte der Erziehung im 20. Jahrhundert (Munich: DVA, 2009); Vern Bullough, 'Children and Adolescents as Sexual Beings: A Historical Overview', Child and Adolescent Psychiatric Clinics of North America, 13 (2004), 447-59; John Gillis, 'The birth of the virtual child: a victorian progeny', in Willem Koops and Michael Zuckerman (eds), Beyond the Century of the Child: Cultural History and Developmental Psychology (Philadelphia: University of Pennsylvania Press, 2003), 82-95; Michael Zuckerman, 'The millennium of childhood that stretches before $u$ s', in Koops and Zuckerman (eds), ibid., 225-42; James Kincaid, Child-Loving: The Erotic Child and Victorian Culture (New York: Routledge, 1992), ch. 2; Harry Hendrick, Children, Childhood and English Society, 1880-1990 (Cambridge: Cambridge University Press, 1997), ch. 2; Hugh Cunningham, Children and Childhood in Western Society Since 1500 (London: Longman, 1995); Roger Cooter, 'Introduction', in idem (ed.), In the Name of the Child: Health and Welfare, 1880-1940 (London: Routledge, 1992), 1-18; Jacques Gélis, 'Die Individualisierung der Kindheit', in Philippe Ariès and Roger Chartier (eds), Von der Renaissance zur Aufklärung, Holger Fliessbach and Gabriele Krüger-Wirrer (trans.) (Frankfurt: Fischer, 1991) (Geschichte des privaten Lebens, Vol. 3), 313-31; Stevi Jackson, Childhood and Sexuality (Oxford: Blackwell, 1982), 22-43; from a sociologist's point of view, Chris Jenks, Childhood (London: Routledge, 1996).

${ }^{10}$ American psychologist, G. Stanley Hall (1844-1924), whose research focused on childhood development and evolutionary theory, is credited with shaping the concept of adolescence around 1900 and popularising it in America and Europe with his comprehensive two-volume tome Adolescence: Its Psychology and Its Relations to Physiology, Anthropology, Sociology, Sex, Crime, Religion and Education (New York: Appleton, 1904); see also, Jon Savage, Teenage: The Creation of Youth Culture (London: Viking Penguin, 2007), 66-73; Jeffrey Moran, Teaching Sex: The Shaping of Adolescence in the Twentieth Century (Cambridge, MA: Harvard University Press, 2000), 1-4, 14-22; on the 'invention' of the Jugend (youth) in Germany around 1900, Sterling Fishman, 'Suicide, Sex, and the Discovery of the German Adolescent', History of Education Quarterly, 10 (1970), 170-88: 171-3; John Gillis, Youth and History: Tradition and Change in European Age Relations, 1770-Present (New York: Academic Press, 1981), chs 4 and 5.

${ }^{11}$ Sarah Toulalan, "Unripe” bodies: children, sex and the body in early modern England', in Sarah Toulalan and Kate Fisher (eds), Bodies, Sex and Desire from the Renaissance to the Present (Basingstoke: Palgrave, 2011), 131-50.

12 Sander Gilman, 'Male stereotypes of female sexuality in Fin-de-Siècle Vienna', in idem (ed.), Difference and Pathology: Stereotypes of Sexuality, Race and Madness (Ithaca, NY: Cornell University Press, 1985), 39-58.
} 
Finally, my paper suggests that the tensions among Moll, Freud and several other contributors to the debate may indeed distract attention from the fact that their conceptualisations of childhood sexuality shared more similarities than differences. This contradicts sexologist Gunter Schmidt's interpretation of Freud, whom he sees as a representative of a heterological understanding of child sexuality, in contrast to Moll's homological approach. ${ }^{13}$ With the notable exceptions of childhood and youth psychologists Stern and Bühler, I argue that all contributors to this debate - in one way or the other - portrayed infant and childhood sexuality as homologous to that of adults.

\section{The Emergence of Interest in Childhood Sexuality}

Prior to the eighteenth century, there was a widely held notion that, as a result of original sin, children were evil, naturally wicked and corrupt. In the eighteenth century, educators recommended a strict upbringing to form children into healthy and moral human beings. ${ }^{14}$ In particular, theologians, the clergy, pedagogues and physicians became acutely concerned about the dangers of children masturbating. Within these discourses the masturbating child was portrayed as morally, physically and mentally diseased and eventually doomed. ${ }^{15}$ Hence, anti-masturbation campaigns of the eighteenth-century Enlightenment aimed at protecting children's sexual innocence by warning them of the dangers of masturbation and demanding a high level of self-control. ${ }^{16}$

The second half of the eighteenth century saw a fundamental shift in the understanding of children. ${ }^{17}$ Figures such as the Genevan philosopher and pedagogue Jean-Jacques Rousseau (1712-78) and the German philosopher, theologian and poet Johann Gottfried Herder (1744-1803) suggested a different understanding of the child that recognised the child in its own right and as categorically distinct from the adult. Children, they argued, had their own way of thinking and feeling. Rousseau, whose educational novel Émile became an influential and widely read practical pedagogic guidebook by the end

${ }^{13}$ Gunter Schmidt, 'Kindersexualität - Konturen eines dunklen Kontinents', Zeitschrift für Sexualforschung, 17 (2004), 312-22.

${ }^{14}$ Andreas Schulz, 'Der "Gang der Natur" und die "Perfektibilität" des Menschen: Wissensgrundlagen und Vorstellungen von Kindheit seit der Aufklärung', in Lothar Gall and Andreas Schulz (eds), Wissenskommunikation im 19. Jahrhundert (Stuttgart: Steiner, 2003), 15-39: 23, 25; Anne Higonnet, The History and Crisis of Ideal Childhood (London: Thames and Hudson, 1998); Kincaid, op. cit. (note 9), 172-6; Franz Eder, Kultur der Begierde: Eine Geschichte der Sexualität (Munich: Beck, 2002), 83-5; Gélis, op. cit. (note 9), 323-6; Jacques Revel, 'Vom Nutzen der Höflichkeit', in Ariès and Chartier (eds), op. cit. (note 9), 173-211: $179-87$.

15 There is an abundance of historiography discussing the eighteenth-century anti-masturbation campaigns, including Thomas Laqueur, Solitary Sex: A Cultural History of Masturbation (New York: Zone, 2003); Patrick Singy, 'The History of Masturbation: An Essay Review', Journal for the History of Medicine and Allied Sciences, 59 (2004), 112-21; Michael Stolberg, 'An Unmanly Vice: Self-Pollution, Anxiety, and the Body in the Eighteenth Century', Social History of Medicine, 13 (2000), 1-21; idem, 'The Crime of Onan and the Laws of Nature: Religious and Medical Discourses on Masturbation in the Late Seventeenth and Early Eighteenth Centuries', Paedagogica Historica, 39 (2003), 701-17; Eder, op. cit. (note 14), 92-127; Karl Braun, Die Krankheit Onania. Körperangst und die Anfänge der modernen Sexualität im 18. Jahrhundert (Frankfurt: Campus, 1995).

${ }^{16}$ Karl Braun, “ “Gläserne Körper”? Sexualaufklärung in Deutschland 1770-1800', Hessische Blätter für Volksund Kulturforschung, NF 31 (1996), 89-101; Charles Taylor, Sources of the Self: The Making of Modern Identity (Cambridge, MA: Harvard University Press, 1989), 173-5.

${ }^{17}$ Meike Sophia Baader, Die romantische Idee des Kindes und der Kindheit: Auf der Suche nach der verlorenen Unschuld (Neuwied: Luchterhand, 1996), 35-66; Hans-Heino Ewers, Kindheit als poetische Daseinsform: Studien zur Entstehung der romantischen Kindheitsutopie im 18. Jahrhundert: Herder, Jean Paul, Novalis und Tieck (Munich: Fink, 1989), chs 1 and 2. 
of the eighteenth century throughout Europe, rejected the old idea of children's original sin and believed in their general sexual 'innocence'. ${ }^{18}$ He argued that because children were innocent they were not aware of shame: "A sense of shame proceeds only from the knowledge of evil; and how can children who neither have, nor ought to have this knowledge, shew its effects?' Rousseau, therefore, objected to any form of moral teaching to children as this would make them aware 'that there are things shameful and immodest; it is inspiring them with a secret desire of knowing these things. ${ }^{19}$ The critical stage of childhood only arrived with puberty when children became aware of $\sin .{ }^{20}$ Until then, they should be treated very carefully to ensure their innocence: 'I see but one certain method of preserving the innocence of children, namely, that it be cherished and respected by those who surround them; otherwise the artifice and reserve with which they are treated, will, sooner or later, infallibly be discovered.' ${ }^{21}$ Hence, according to eighteenth-century pedagogical thinking, children were best to be segregated from the dangerous influence of modern society, particularly in cities, and to be kept under surveillance by parents and educators.

With the increasing attention paid to children in the course of the late eighteenth and nineteenth centuries, the belief in children being sinful and evil eventually lost its appeal. $^{22}$ The emphasis on surveillance and regulation of infants and children shifted towards protection by the central and local state and the legal system of civil society. In Germany, this can be seen, for instance, in the discussions about the age of consent for sexual relations which the Prussian state raised from twelve to 14 years in $1851 .^{23}$ As reflected in the scientific as well as popular anti-masturbation campaigns, official discourses continued portraying the 'normal' child as asexual and innocent. Masturbation in the nineteenth century became increasingly understood as a medical problem and, in particular, as a psychological one, with physicians describing sexual feelings in children as deviant and pathological. ${ }^{24}$ It was very clear for the nineteenth-century doyen of sexology, Richard von Krafft-Ebing (1840-1902), that masturbation and childhood sexuality were central to the aetiology of perversion. ${ }^{25}$ The child, therefore, was seen not only in need of moral but also medical treatment.

In Germany, these changes in the discourse about masturbation were part and parcel of a more scientific and medical approach to children and their upbringing and the

\footnotetext{
18 Jean-Jacques Rousseau, Emilius; or, a Treatise of Education, (Émile, ou, De l'éducation, 1762), 3 vols (Edinburgh: Donaldson, 1768); see Schulz, op. cit. (note 14), 19; on Rousseau's notion of the 'innocent child', see Mary McAlpin, 'Innocence of Experience: Rousseau on Puberty in the State of Civilization', Journal of the History of Ideas, 71 (2010), 241-61; Taylor, op. cit. (note 16), 357.

${ }^{19}$ Rousseau, ibid., Vol. 2, Book 4, 12.

${ }^{20}$ Ibid., 1-10.

21 Ibid., 12.

22 Schulz, op. cit. (note 14), 19-32; Gebhardt, op. cit. (note 9), 37.

23 (Johann Ludwig) Casper, 'Ueber Nothzucht und Päderastie und deren Ermittlung Seitens des Gerichtarztes. Nach eigenen Beobachtungen', Vierteljahrsschrift für gerichtliche und öffentliche Medicin, 1 (1852), 21-78; Eder, op. cit. (note 14), 83-5.

${ }^{24}$ Lesley Hall, " "It was Affecting the Medical Profession": The History of Masturbatory Insanity Revisited', Paedagogica Historica, 39 (2003), 685-99; George Makari, 'Between Seduction and Libido: Sigmund Freud's Masturbation Hypotheses and the Realignment of his Etiologic Thinking, 1897-1905', Bulletin of the History of Medicine, 72 (1998), 638-62: 645-7.

${ }^{25}$ Richard von Krafft-Ebing, Psychopathia sexualis: Mit besonderer Berücksichtigung der conträren Sexualempfindung: Eine medizinisch-gerichtliche Studie für Ärzte und Juristen (Stuttgart: Enke, 1886), 7th rev. edn 1892, eg. 28, 38-9, 50; cf. Harry Oosterhuis, Stepchildren of Nature: Krafft-Ebing, Psychiatry, and the Making of Sexual Identity (Chicago: University of Chicago Press, 2000), 57, 131-3, 142, 161-4.
} 
institutionalisation of childhood research from the mid-nineteenth century. Subsequently, a 'scientific-psychological' approach to childhood research emerged, leading to greater medical interest in children's behaviour and its neurological basis, and to reforms in pedagogical thinking. ${ }^{26}$ With more paediatricians and numerous institutions available to advise mothers on how to bring up their children, parents increasingly trusted and relied upon experts' medical, psychological and pedagogical recommendations. As Miriam Gebhardt argued, the upbringing of children turned into an 'expert-led everyday experience' for parents. ${ }^{27}$ It was in this context of the emerging medico-scientific research about childhood that paediatricians and psychologists also became interested in questions of sexuality.

Another reason for a growing interest in issues of childhood sexuality was that, during the second half of the nineteenth century, sexuality became acknowledged as a key factor in the making of personal identities. The shaping of sexual identity came to be understood as being part of the personal biography, reaching back to early childhood. ${ }^{28}$ At the beginning of the twenty-first century, interest in child sexuality and its history is also fuelled by debates on paedophilia, and an abundant number of cases of sexual abuse of children reported by the media, as well as by survivors, in the hugely popular 'misery literature'. 29

\section{The Discourse about Childhood Sexuality in the Second Half of the Nineteenth Century}

During most of the nineteenth century, child sexuality was conceptualised in terms of pathologies, where the 'normal' child was believed to be lacking sexual feelings. Most authors referred to expressions of children's sexuality in terms such as 'depravity' or 'evil' (Laster or Übel). ${ }^{30}$ Masturbation, the main such 'evil' performed by children, was seen as pathological and had to be treated medically. Psychiatrist Friedrich Scholz (1831-1907), for instance, described immoral behaviour in children which he thought was triggered by an hereditary 'inverted instinct' or by precocious sexual development, perhaps caused

\footnotetext{
${ }^{26}$ Jonathan Gillis, 'Bad Habits and Pernicious Results: Thumb Sucking and the Discipline of Late-NineteenthCentury Paediatrics', Medical History, 40 (1996), 55-73; 61; Schulz, op. cit. (note 14), 24-39; Gebhardt, op. cit. (note 9), 40-1, 49-50.

${ }^{27}$ Gebhardt, op. cit. (note 9), 24. This and all subsequent translations, unless otherwise stated, are the author's own.

${ }^{28}$ Michel Foucault, The History of Sexuality, Vol. 1, R. Hurley (trans.) (New York: Pantheon, 1978); Roy Porter and Lesley Hall, The Facts of Life: The Creation of Sexual Knowledge in Britain, 1650-1950 (New Haven: Yale University Press, 1995), ch. 7; Oosterhuis, op. cit. (note 25); Oosterhuis' paper in this issue; Philipp Sarasin, Reizbare Maschinen: Eine Geschichte des Körpers 1765-1914 (Frankfurt: Suhrkamp, 2001), in particular ch. 5; Eder, op. cit. (note 14), chs 4 and 5; Schmidt, op. cit. (note 13).

${ }^{29}$ For instance, George Rousseau, 'Introduction', in idem (ed.), Children and Sexuality: From the Greeks to the Great War (New York: Palgrave Macmillan, 2007), 1-38; R. Danielle Egan and Gail Hawkes, 'Imperiled and Perilous: Exploring the History of Childhood Sexuality', Journal of Historical Sociology, 21 (2008), 355-67; R. Danielle Egan and Gail Hawkes, 'Producing the Prurient through Pedagogy of Purity: Childhood Sexuality and the Social Purity Movement', Journal of Historical Sociology, 20 (2007), 443-61; Brigitte Kerchner, “"Unbescholtene Bürger" und "gefährliche Mädchen” um die Jahrhundertwende: Was der Fall Sternberg für die aktuelle Debatte um sexuellen Mißbrauch an Kindern bedeutet', Historische Anthropologie, 6 (1998), 1-32. About changing concepts of child abuse in the twentieth century, see Ian Hacking, 'The Making and Molding of Child Abuse', Critical Inquiry, 17, 2 (1991/2), 253-88. About the booming market of 'misery literature', see Esther Addley, 'So Bad It's Good', The Guardian, G2, 15 June 2007, 4, online: http://www.guardian.co.uk/ society/2007/jun/15/childrensservices.biography, accessed 6 June 2011; Brendan O'Neill, 'Misery Lit... Read On', BBC News, 17 April 2007, online: http://news.bbc.co.uk/1/hi/magazine/6563529.stm, accessed 6 June 2011.

${ }^{30}$ Carter, op. cit. (note 4), 196.
} 
by the 'poisoning of fantasy' ${ }^{31}$ In 1883 , one of the leading paediatricians in Imperial Germany, Eduard Henoch (1820-1910), claimed to have learnt about cases of children as young as two years old masturbating but was confident that at such a young age they could easily be treated. In contrast to most of his colleagues, ${ }^{32}$ he was less sure about the extent to which masturbation caused hysteria. In his opinion, masturbation was far too widespread to be the sole cause of hysteria; instead, he presumed an additional underlying 'nervous predisposition'. 33

A few years earlier, in 1879, a physician from Budapest, Sámuel Lindner (c. 1842-1911), ${ }^{34}$ published a paper presenting his research and classification of different forms of thumb and finger sucking by infants and children, which he called Ludeln. Lindner found this behaviour to be very common amongst children and described it as 'a blissful sucking' (Wonnesaugen) which could lead to very intense and lustful, even ecstatic feelings, especially when the child simultaneously touched the genitals. Although his sample included only four such cases, amongst them a boy aged one and a girl aged six, he suggested a close connection between this sucking and fondling of the genitals and even illustrated this with a drawing of the six-year-old girl. ${ }^{35}$ Hence, in a very powerful way, Lindner's article introduced a sexual interpretation of infantile thumb sucking that was picked up by several other discourses, including paediatric and psychological, thereby strengthening the connection of this infant behaviour with masturbation. ${ }^{36}$ As Jonathan Gillis demonstrated, the similarity between the two habits that Lindner had implied, 'led covertly to the widening of the idea of infant sexuality'. ${ }^{37}$

Lindner's publication became a key reference for subsequent authors writing about sexual experiences of children. Amongst them was a Viennese physician, Wilhelm Stekel (1868-1940). In 1895, seven years before he approached Freud and became one of his key followers, Stekel published an article 'On Coitus in Childhood' claiming that 'coitus in early childhood was not such a rare occurrence'. He was convinced that just about every other educated person would remember certain experiences from childhood which they did not understand at the time, but which they would recognise now as the onset of their libido. Although 'cases of real coitus are rare', children were often surprised by salacious feelings (Wollustgefühle) when touching or just seeing the genitals of others. ${ }^{38}$ Stekel attributed the emerging sexual feelings to the human instinct and understood them as a result of masturbating from a young age.

\footnotetext{
${ }^{31}$ Friedrich Scholz, Die Charakterfehler des Kindes: Eine Erziehungslehre für Haus und Schule (Leipzig: Mayer, 1891), 151-2.

32 On the discussion during the second half of the nineteenth century about masturbation as a cause for hysteria, see Carter, op. cit. (note 4).

${ }^{33}$ Eduard Henoch, Vorlesungen über Kinderkrankheiten: Ein Handbuch für Ärzte und Studierende (Berlin: Hirschwald, 1883), lecture on 'Hysterische Affektion', 193-211: 207.

${ }^{34}$ Entry in centropa.hu, online: http://www.centropa.hu/index.php?nID=15\&x=PXVuZGVmaW51ZDsgc2V hcmNoVHlwZT1waG90b2RldGFpbDsgc2VhcmNoVmFsdWU9YXJjaC9odW4vc2FyZGkwNDsgc2Vhcm NoU2tpcD0wOyBvcmlTVD1uYW11OyBvcmlTVj1CdXJnZXI=, accessed 6 June 2011. I am grateful to Gábor Szegedi (Budapest) for helping me to identify Lindner.

35 Sámuel Lindner, 'Das Saugen an den Fingern, Lippen etc. bei den Kindern (Ludeln): Eine Studie', Jahrbuch für Kinderheilkunde und physische Erziehung, 14 (1879), 68-91: 73-4, 81-2 and 89.

36 See Gillis, op. cit. (note 26), 57-61 and 67-8.

37 Ibid., 61.

${ }^{38}$ Wilhlem Stekel, 'Ueber Coitus im Kindesalter: Eine hygienische Studie', Wiener medizinische Blätter, 18, 16 (1895), 247-9: 247.
} 
Although Stekel was clear about the ravaging effects of masturbation, he did not see any specific risk to the child's health through sexual intercourse. ${ }^{39} \mathrm{He}$ finally recommended that parents monitor their children closely and keep all temptations and improper stimulations away from them. For instance, boys and girls should have separate bedrooms; beyond the age of four, children should not sleep together with their parents and they should not be allowed in the bed of a child minder or servant. During the night, boys should be regularly checked for erections. Out of concern about improper behaviour of children, Stekel rejected co-education at school and recommended that boys and girls should only be allowed to play together when watched and never in a dark location. ${ }^{40}$

At the same time, in the 1890s, Sigmund Freud was very clear in his denial of an innate sexual drive in infants and young children. He argued that if children showed any form of sexual activity, including masturbation, this was caused by an act of abuse or seduction by an adult or an older child. ${ }^{41}$ The effect of this, Freud believed, would not immediately become visible in infancy or childhood but only after the child had entered puberty. Then, the sexual experience would be retrieved from the subconscious and revived by the young person, causing all sorts of neurotic symptoms. ${ }^{42}$ The infant or young child, however, was unable to comprehend the act of seduction and abuse at the time. ${ }^{43}$

In the 1890s, despite many diverse and contradictory theories, most authors agreed that precocious sexual activities in childhood were indicative of a congenital predisposition to perversion. Even Stekel acknowledged that an early onset of sexual feelings could weaken the body and lead to 'neurasthenia sexualis' ${ }^{44}$ However, this belief was challenged by three authors: sexologist and psychologist Albert Moll, psychologist and philosopher Max Dessoir (1867-1947), and sexologist Henry Havelock Ellis (1859-1939). They all asserted that the history of patients diagnosed as suffering from perversion did not differ significantly from those regarded as normal.

\footnotetext{
39 Ibid., 248.

40 Ibid., 249.

${ }^{41}$ Sigmund Freud, 'Zur Ätiologie der Hysterie (1896)', in idem, Studienausgabe, op. cit. (note 6), Vol. 6, 51-81: 75; also in idem, Gesammelte Werke, op. cit. (note 6), Vol. 1 (London: Imago, 1952), 425-59. Freud's letters to Fließ allow us to follow closely the development of his thinking about sexual experiences in childhood, and seduction and masturbation as causes of neurosis; see Jeffrey Moussaieff Masson (ed.), Sigmund Freud: Briefe an Wilhelm Fliess 1887-1904 (Frankfurt: Fischer, 1986), eg. letters 24 (30 May 1893); 33 (27 November 1893); 42 (21 May 1894); 75 (8 October 1895); 76 (15 October 1895). In letter 77 (16 October 1895), he explained to Fließ that he was 'quite sure' that his 'formula of infantile sexual shock and sexual lust' (Sexualschreck und Sexuallust) was the answer to the mystery of neurosis (Masson (ed.), ibid, 148). In the mid-1890s, cases from Freud's psychoanalytical practice confirmed him in the seduction theory; see eg. letters 80 (2 November 1895); 112 (6 December 1896); 116 (11 January 1897); and 125 (28 April 1897). On Freud's seduction theory, Allen Esterson, 'The Mythologizing of Psychoanalytic History: Deception and Self-Deception in Freud's Accounts of the Seduction Theory Episode', History of Psychiatry, 12 (2001), 329-52; Makari, op . cit. (note 24); Han Israëls and Morton Schatzman, 'The Seduction Theory', History of Psychiatry, 4 (1993), 23-59: 26-39.

42 Freud, Ätiologie der Hysterie, ibid., 74-6.

43 Sigmund Freud, 'L'hérédité et l'étiologie des névroses' ['Heredity and the Aetiology of the Neuroses'] (1896), in idem, The Standard Edition of the Complete Psychological Works of Sigmund Freud, James Strachey, in collaboration with Anna Freud (eds), 24 vols (London: Hogarth Press and the Institute of Psycho-Analysis, 1943-74), Vol. 3, 1962, 141-56: 152-4; also in Freud, Gesammelte Werke, op. cit. (note 6), Vol. 1 (London: Imago, 1952), 407-22: 419.

${ }^{44}$ Stekel, op. cit. (note 38), 249.
} 


\section{A New Understanding of Childhood Sexuality: Albert Moll}

Albert Moll was among the first to question the dominant assumption that masturbation practised in childhood inevitably led to perversion, including homosexuality, in adulthood. In his 1891 treatise on homosexuality, Die conträre Sexualempfindung, he reported a case of epidemic mutual masturbation at a Berlin boarding school. None of the boys involved turned into a homosexual in adulthood. Although Moll knew the names of most of Berlin's homosexuals (Urningen), so he claimed, he was not aware that any of the former pupils of this boarding school were amongst them. Rather, from most of them he knew that they had 'normal', that is, heterosexual, feelings and intercourse. ${ }^{45}$

What helped Moll to develop his argument further was a paper on the development of human sexuality that his Berlin colleague, Max Dessoir, had published in 1894. In this paper, Dessoir distinguished two phases in the development of the human sex drive. ${ }^{46}$ The first phase was characterised by an 'undifferentiated sexual feeling' (undifferenziertes Geschlechtsgefühl) and appeared in girls between the age of twelve and fourteen years and in boys between the age of thirteen and fifteen years, that is, at about the time they entered puberty. In this phase, Dessoir argued, pubescent children did not show a clear sexual orientation; they were neither heterosexual nor homosexual and could even become sexually interested in animals or show other perverse orientations. Crucially, Dessoir's psychology of the vita sexualis did not perceive this as a sign of degeneration or pathological development in the majority of cases, but regarded it as 'normal' ${ }^{47}$ Only later in life should such an undifferentiated sexual orientation be regarded as pathological. ${ }^{48}$ This first phase was followed by a phase in which sexual orientation became differentiated as either heterosexual or homosexual. ${ }^{49}$ Dessoir explained that a hitherto unspecific or 'blurred' sexual drive would then become specific, generally in a heterosexual direction. ${ }^{50}$

Moll used Dessoir's theory of these two phases, but criticised him for only paying attention to the physical changes in puberty and not to the psychological changes which, Moll believed, could begin much earlier. In his book on the Libido sexualis, published in 1898, he therefore extended Dessoir's first undifferentiated phase back to childhood before the onset of puberty. He argued that homosexual or other perverse tendencies in early childhood would disappear in many cases, with a 'normal' heterosexual desire emerging later in puberty. This, he believed, even applied to sadistic or masochistic tendencies. ${ }^{51}$

By extending the undifferentiated phase back into early childhood, Moll then suggested - again in contrast to most of his eminent colleagues at the time, including Freud - that one could already detect an emerging sexual drive in children. Moll redefined this sexual drive in general by distinguishing two elements which he termed the 'detumescence-impulse'

\footnotetext{
45 Albert Moll, Die konträre Sexualempfindung (Berlin: Fischer's Medicinische Buchhandlung, 1891), 167 (note 2 ). In the third and largely extended edition, Moll listed further such examples, in order to make an even stronger case for his argument about the normality of children's sexuality; ibid., 3rd rev. edn (1899), 374-5 (note 2).

${ }^{46}$ Max Dessoir, 'Zur Psychologie in der Vita sexualis', Allgemeine Zeitschrift für Psychiatrie und psychischgerichtliche Medizin, 50 (1894), 941-75.

47 Ibid., 942.

48 Ibid.

${ }^{49}$ Ibid., 947.

50 Ibid., 948 .

51 Albert Moll, Untersuchungen über die Libido sexualis (Berlin: Fischer's Medicinische Buchhandlung, 1898), 421-5 and 325, note. Moll did not entirely agree with Dessoir's definition of the first phase as undifferentiated. Instead, he assumed that the sexual drive in childhood was not always undifferentiated, as in some cases a heterosexual tendency in childhood remained heterosexual after puberty, and likewise a homosexual tendency continued after puberty (ibid., 426-7).
} 
(Detumescenztrieb) and the 'contrectation-impulse' (Kontrektationstrieb). ${ }^{52}$ Whereas detumenscence was a well-established notion in nineteenth-century medical terminology to describe the shrinking of a swelling or a tumour, ${ }^{53}$ the notion of contrectation has mostly been used in a judicial context with the meaning of unlawful appropriation, and only rarely in a medico-legal context, for instance to describe the union of two people for the purpose of procreation. 54

Moll used detumescence for the impulse in men and women 'to bring about a transformation in the genitals'. ${ }^{55} \mathrm{He}$ understood this change in the condition of the male and female genitals physiologically as a drop in blood flow in the spongy body of the genitals and an erection going flaccid, or as an ejaculation; but he also meant it psychologically as a decrease of feeling in the genitals when satisfaction had been achieved. ${ }^{56}$ The term 'contrectation-impulse' Moll introduced to explain the impulse to approach, touch and kiss another person, 'normally' from the opposite sex. He saw this part of the sex drive as being of a mental and sensual nature. ${ }^{57}$

Either of these two aspects of the sexual drive could develop first and, crucially, as Moll claimed, in early childhood. ${ }^{58}$ For this, he gave historical examples of writers such as Dante, the Italian dramatist Vittorio Alfieri, Lord Byron and the Italian sculptor Antonio Canova, who all claimed to have experienced erotic feelings, ie. the contrectation-impulse, in early childhood, hence, long before the onset of puberty. ${ }^{59}$ Moll reported cases of children aged five or six where, deriving from the sexual drive, affections for the other sex could be observed. ${ }^{60}$ At the same time, one could witness violent scenes of jealousy and a clear sense of shame in childhood as well, which Moll interpreted as 'sexual feelings' - in contrast to 'social feelings' - and likened them to those in adulthood. ${ }^{61}$

Similar observations in animals were made by psychologist and professor of philosophy at Gießen, Karl Groos (1861-1946). Moll must have read Groos' study on the play of animals shortly after its publication in 1896 , because he referred to it several times. ${ }^{62}$ Groos saw certain games of young animals and human beings - such as games involving courtship or nursing babies - not as an imitation of adult behaviour but, in Moll's words,

52 Ibid., 8-11.

${ }^{53}$ For instance, in Johann Erdwin Christoph Ebermaier, Taschenbuch der Chirurgie für angehende practische Aerzte und Wundärzte, 3rd rev. edn (Leipzig: Barth, 1819), Vol. 2, 545.

${ }^{54}$ For instance in the journal Rechtsprechung und Medizinal-Gesetzgebung, 7 (1897), 453.

55 ‘an den Genitalien eine Veränderung herbeizuführen', Moll, op. cit. (note 51), 10.

56 Ibid., 10 (note 1).

${ }^{57}$ Ibid., 10.

${ }^{58}$ Ibid., 44-5. Although having interviewed many people, Moll was unable to find out which of the two developed first more often, but presumed that in most cases the impulse to touch the genitals, the Detumescenztrieb, developed first (ibid., 54). This would be supported by the observations of the Italian psychiatrist and director of the asylum in Catanzaro, Silvio Venturi (1850-1900), who, according to Moll, suggested that temporary masturbation could be explained physiologically, Silvio Venturi, Le degenerazioni psico-sessuali nella vita degli individui e nella storia delle societa (Turin: Bocca, 1892), 6-8.

${ }^{59}$ Moll, op. cit. (note 51), 43-4.

60 Ibid., 44.

${ }^{61}$ Ibid., 55. However, even those social feelings, such as a child's love for the parent, could have a sexual element, for instance, when the child experienced pleasure (Lust) when kissing the mother, or jealousy when the mother paid more attention to another child. R. Speyer reported of several cases of children showing passionate feelings of love, jealousy and hatred (towards other children or adults) in letters, R. Speyer, 'Die Liebe bei den Kindern', Zeitschrift für Kinderforschung, 9, 1 (1904), 21-5.

${ }^{62}$ Karl Groos, Die Spiele der Thiere (Jena: Fischer, 1896). Moll referred to pages 6, 230-2, and 253-5. 
as an adaptive 'pre-activity' (Vorahmung) in preparation for adulthood. ${ }^{63}$ Moll concluded 'that these observations in the animal world are immensely important for destroying the belief that physical puberty is a precondition for the sexual inclination of the sexes. ${ }^{64}$ However, he found it impossible to decide whether, as Groos suggested, this was just playing or whether, as he himself was inclined to think, these games could indeed be linked to the adult sexual drive. ${ }^{65}$

Not only could the contrectation-impulse develop long before the genitals matured during puberty, but so too could the detumescence-impulse. Contrary to what was generally believed at the time, Moll claimed that this impulse to induce a change in the genitals could also emerge in early childhood, before the onset of puberty, and could lead to 'the most excessive acts of masturbation', despite a boy, for instance, still being unable to ejaculate. ${ }^{66} \mathrm{He}$ interpreted this as a clear sign of the existence of the detumescenceimpulse in children. 'It is a kind of voluptuous feeling, a sort of tickle that such persons experience or want to experience at their genitals; and in doing so an erection could happen long before puberty.' This was the reason why, according to Moll, children as young as one or two years old were masturbating. ${ }^{67}$

Finally, Moll suggested that both impulses could develop simultaneously before the onset of puberty. He quoted a case of a seven-year-old girl who had touched the genitals of her three-and-a-half-year-old brother. Likewise, the girl had allowed her younger brother to touch her genitals and, from time to time, she had touched herself. Furthermore, it emerged that the girl blushed in the presence of her brother. It was believed that the girl had developed a certain sexual affection for her brother. According to Moll's libido theory, this girl showed clear signs of both the detumescence-impulse and the contrectation-impulse. ${ }^{68}$

To what extent the appearance of these two drives was related to the activities of the gonads was not entirely clear to Moll. ${ }^{69}$ He thought it possible that there were cases in which the gonads matured at an earlier age than they normally would and without the body showing any other sign of puberty. ${ }^{70}$ Hence, one had to be very careful to conclude that in cases where young children had developed signs of a 'psycho-sexual puberty' these were not the result of activity of the gonads. Moll suspected that in some cases a psychosexual puberty could occur without the gonads having matured but assumed that the gonads were still the trigger, albeit in a different way. Either way, Moll emphasised the importance of the gonads for the sexual life because, in his view, they triggered the contrectation-impulse and detumescence-impulse. ${ }^{71}$

\footnotetext{
63 Moll, op. cit. (note 51), 44, 437.

64 '[D]ass diese Beobachtungen in der Tierwelt ungemein wichtig sind, um den Glauben zu zerstören, dass die körperliche Pubertät eine Vorbedingung für die sexuelle Zuneigung der Geschlechter sei... '. Ibid., 44.

65 Ibid., 45.

66 Ibid., 13-4 ('masslosesten Masturbationsakten').

67 'Es ist auch eine Art Wollustgefühl, eine Art Kitzel, den derartige Personen an den Genitalien empfinden oder empfinden wollen, wobei es lange Zeit vor der Pubertät zu Erektionen kommen kann.' Ibid., 45-6: 46. Moll referred here to a case of a one-and-a-half-year-old girl who was seen playing at her genitals with her fingers, ibid., 50.

68 Ibid., 46-7.

${ }^{69}$ On the contemporary knowledge about hormones and the function of the gonads, see Chandak Sengoopta, The Most Secret Quintessence of Life: Sex, Glands, and Hormones, 1850-1950 (Chicago, IL: University of Chicago Press, 2006), ch. 2. Moll did not make any reference to the emerging endocrinological literature.

${ }^{70}$ Moll, op. cit. (note 51), 50-1.

${ }^{71}$ Ibid., 51-2. However, Moll made a distinction between the two drives. The detumescence-impulse, he thought, was a direct consequence of the gonads, at least in men, whereas in women during intercourse the detumescenceimpulse was separated from the functioning of the gonads. Originally, in men, the detumescence-impulse was
} 
Inspired by Dessoir and Groos, Moll had, by the end of the 1890s, formulated a groundbreaking new evolutionary theory of the sexual drive that he believed set in during childhood. ${ }^{72}$ Although the issue of childhood sexuality had been considered since the midnineteenth century, and in particular during the 1890s, Moll's analysis was more detailed, wide ranging and considerate than that of any of his contemporaries, bringing together the, so-far, rather sporadic evidence. In his view, childhood sexuality was grounded in the biology of the body, in particular related to the gonads and, therefore, part of 'normal' development - although he struggled to explain how exactly the physiology of the gonads worked. In contrast to mainstream theories of the time, Moll had come up with a theoretical explanation of the 'natural' character of childhood sexuality which he illustrated and substantiated with numerous case studies. This was, counter to Frank Sulloway's assertion, new for the time and quite revolutionary. ${ }^{73}$

\section{The Significance of Moll's Theory of Childhood Sexuality}

Although Moll's book did not receive very many reviews in academic journals, it did not go unnoticed. ${ }^{74}$ Havelock Ellis must have read it immediately upon publication in 1897 , because he quoted the book in a paper on masturbation published in the following year. ${ }^{75}$ In this paper, Ellis mentioned, more or less in passing, that ' $[t]$ here appears to be no limit to the age at which spontaneous masturbation may begin to appear. ${ }^{, 76} \mathrm{He}$ did not see any need for further elaboration on this claim, although it was still remarkable for the time. His own research, based on interviews with 'normal persons', revealed to him that some of the interviewees had felt 'voluptuous sensations from casual contact with the sexual organs' at a very young age; others had even experienced an 'occasional slight orgasm from early years'. Some, however, had no such feelings until puberty. ${ }^{77}$ When discussing different techniques for masturbating earlier in the same paper, Ellis quoted a case of an eight-month-old baby girl masturbating, again without any further comment on her young age. ${ }^{78}$ Neither of these experiences was described by Ellis as pathological. Although the main focus of his paper was on masturbation in adolescence and adulthood, it is quite striking that he saw no reason to elaborate much further on the sexual experiences of these children.

nothing more than the urge to empty glandular secretions, an urge Moll likened to the urge to empty one's full bladder (ibid., 52-3). The contrectation-impulse, in contrast, he interpreted as an indirect consequence of the gonads that could only be understood from an evolutionary perspective in relation to the purpose of the genitals (ibid., 53). Moll explained this indirect effect of the gonads as excitement (Erregung) stemming from the testicles or ovaries. This excitement, however, he understood to be probably independent from the secretion of semen or from ovulation (ibid., 55).

72 See for instance, Oosterhuis, op. cit. (note 25), 46.

73 Sulloway, op. cit. (note 5), 430.

${ }^{74}$ An anonymous review appeared in Journal of Mental Science, 44 (1898), 347-9; and Albert Eulenburg reviewed the book for the Deutsche medizinische Wochenschrift, 27 (1901), 26.

${ }^{75}$ Havelock Ellis, 'Auto-Erotism: A Psychological Study', The Alienist and Neurologist, 19 (1898), 260-99; cf. Ivan Crozier, 'Introduction: Havelock Ellis, John Addington Symonds and the construction of "sexual inversion"', in idem (ed.), Havelock Ellis and John Addington Symonds, Sexual Inversion: A Critical Edition (Houndsmills: Palgrave Macmillan, 2008), 1-86.

${ }^{76}$ Ellis, ibid., 283.

77 Ibid., 283-4.

${ }^{78}$ Ibid., 270; Ellis referred to a paper by Charles Townsend, 'Thigh Friction in Children Under One Year', Transactions of the American Pediatric Society, 8 (1896), 186-9. 
Some of Moll's colleagues were eagerly awaiting the second volume of his Libido sexualis that he had promised but never delivered. This was the reason why, according to the eminent Berlin neurologist and sexologist Albert Eulenburg (1840-1917), the leading German medical journal, Deutsche medizinische Wochenschrift, waited for three years before reviewing Moll's book in 1901. Eulenburg commended Moll's research and urged him to publish the second volume of his 'peculiar and undoubtedly important' treatise. ${ }^{79}$ This positive review is particularly noteworthy because, a few years later, Eulenburg sided with one of Moll's opponents when he became the first president of Magnus Hirschfeld's Ärztliche Gesellschaft für Sexualwissenschaft und Eugenik (Medical Society for Sexology and Eugenics) in 1913 (see Volkmar Sigusch's paper in this issue).

Like Ellis, Sigmund Freud must have read Moll's Libido sexualis directly after the publication of the two parts of the book in spring and summer 1897 respectively. ${ }^{80}$ In November 1897, he wrote to Fließ that, to his 'delight', he found in Moll's book an idea similar to his own thinking about the changing roles of the erogenous zones from infancy to adulthood. ${ }^{81}$ In his copy of Moll's book, Freud had marked the central paragraphs in which Moll outlined his view on childhood sexuality. ${ }^{82}$ Freud's decision to discard his seduction theory in autumn 1897, therefore, was not only influenced by his discussions with Fließ, his self-analysis and his frustration over failing to bring any analysis of his patients to a conclusion, ${ }^{83}$ but also, as Sulloway has argued, probably by his reading of Moll's study. ${ }^{84}$ This was a disturbing and embarrassing moment for Freud because KrafftEbing, for instance, had abandoned the seduction theory in the previous year, describing it as a 'scientific fairy tale'. ${ }^{85}$ At the same time, giving up the seduction theory was also a decisive step for Freud and his understanding of childhood sexuality. Many years later, in 1924, he explained that after having 'overcome this error, new insight opened up into spontaneous expressions of infantile sexuality' ${ }^{86}$

79 'das eigenartige und unzweifelhaft bedeutende Werk', Eulenburg, op. cit. (note 74).

${ }^{80}$ Sulloway, op. cit. (note 5), 699-702.

${ }^{81}$ Letter 146 (14 November 1897), Masson (ed.), op. cit. (note 41), 302. See Moll, op. cit. (note 51), 93.

82 See Freud's copy of Moll, op. cit. (note 51), in The Freud Museum, London (shelfmark 1378), 44. According to the Museum's librarian, Keith Davis, it is certain that these marginal markings are from Freud as they are consistent with his writing and annotations in other books. See, on markings in Freud's books and their complexity; Gerhard Fichtner, "Favourite food, books": Freud's library and its significance for his life and work', in J. Keith Davis and Gerhard Fichtner (eds), Freud's Library: A Comprehensive Catalogue / Freuds Bibliothek: vollständiger Katalog (London: The Freud Museum and Tübingen: Edition Diskord, 2006), 9-77: 31-8.

${ }^{83}$ Freud first indicated in September 1897 that he had developed serious doubts about his seduction theory during the previous couple of months; Letter 139 (21 September 1897), Masson (ed.), op. cit. (note 41), 283-5; for detailed accounts of Freud's retreat from his seduction theory, see Esterson, op. cit. (note 41); Israëls and Schatzman, op. cit. (note 41), 39-56.

${ }^{84}$ Sulloway, op. cit. (note 5), 433-5.

85 Oosterhuis, op. cit. (note 25), 88-9; Sulloway, op. cit. (note 5), 433. Moll and Krafft-Ebing regularly corresponded (Sulloway, ibid., 418), and Sulloway suggests that Krafft-Ebing became convinced about the flaws of Freud's seduction theory by Moll's case about epidemic mutual masturbation at a Berlin boarding school, that I have mentioned above.

86 'Nach der Überwindung dieses Irrtums eröffnete sich der Einblick in die spontanen Äußerungen der kindlichen Sexualität...', as Freud explained his change of mind in 1924 in a new footnote to an article he had originally published in 1896 ('Weitere Bemerkungen über die Abwehr-Neuropsychosen'), quote in Masson (ed.), op. cit. (note 41), 285 (note 4). 


\section{Freud and the Sexual Child}

Freud was well aware of such spontaneous signs of sexual feelings in children even before 1897 , but struggled to bring these observations in line with his seduction theory and his theory of psychoneurosis. In 1898, he warned that the sexual life of children did not begin with puberty but earlier, a fact one should not ignore in his opinion. When stating that he had learned that 'children are capable of every psychical sexual activity, and many somatic sexual ones as well', Freud sounded as if he were referring to Moll, but without acknowledging him. ${ }^{87}$ Nevertheless, Freud continued, 'the organisation and evolution of the human species strives to avoid any great degree of sexual activity during childhood' and insisted that sexual experiences during childhood would have a pathological effect in adulthood. ${ }^{88}$

In 1899, however, Freud informed Fließ that his self-analysis had revealed to him that, although nothing sexual had happened during his early childhood, there had been 'a seed of sexual emotion', something he intended to explore further. ${ }^{89}$ The result was Freud's seminal Three Essays on the Theory of Sexuality, published in $1905 .{ }^{90}$ In the second essay, on 'Infantile Sexuality', he claimed 'that germs of sexual impulses are already present in the new-born child and that these continue to develop for a time, but are then overtaken by a progressive process of suppression; this in turn is itself interrupted by periodical advances in sexual development or may be held up by individual peculiarities. ${ }^{91}$ It was only in 1905 that Freud eventually fully agreed with the theory of infant and childhood sexuality.

Still, Freud did not perceive himself as a latecomer but as a frontrunner in this field. $\mathrm{He}$ claimed that, to his knowledge and after going through the relevant literature repeatedly, no other author previously had "clearly recognised the regular existence of a sexual drive in childhood' ${ }^{92}$ With one remark Freud brushed aside all research on childhood sexuality published so far, including Wilhelm Stekel's 1895 article and Albert Moll's research. What is true, though, is that Moll had rejected the idea of sexuality in early infanthood as being 'normal' - he only saw sexuality emerging in children from the age of six or eight as not being pathological. He later argued that infants were actually neutral to sexual feelings during the early years of their life. ${ }^{93}$ Freud, in contrast, had paid great attention to

87 ،... aller psychischer und vieler somatischer Sexualleistungen fähig...', Sigmund Freud, 'Die Sexualität in der Ätiologie der Neurosen (1898)', in idem, Studienausgabe, op. cit. (note 6), Vol. 5, 12-35: 31; also in idem, Gesammelte Werke, op. cit. (note 6), Vol. 1 (London: Imago, 1952), 489-516: 511; English translation: Sigmund Freud, 'Sexuality in the Aetiology of the Neuroses', in idem, Standard Edition, op. cit. (note 43), Vol. 3, 259-85: 280.

${ }^{88}$ Freud, 'Sexualität', ibid., 31; English translation, ibid., 280-1; see also, Sulloway, op. cit. (note 5), 255-6.

89 'Auf die Frage, was in der ersten Kindheit vorgefallen, lautet die Antwort: Nichts, aber es war ein Keim sexueller Regung da.' Letter 188 (3 January 1899), Masson (ed.), op. cit. (note 41), 370.

${ }^{90}$ Davidson, op. cit. (note 7).

91 ،... daß das Neugeborene Keime von sexuellen Regungen mitbringt, die sich eine Zeitlang weiterentwickeln, dann aber einer Fortschreitenden Unterdrückung unterliegen, welche selbst wieder durch regelrechte Vorstöße der Sexualentwicklung durchbrochen und durch individuelle Eigenheiten aufgehalten werden kann'. Freud, 'Drei Abhandlungen', op. cit. (note 6), 84; translation slightly modified, Sigmund Freud, 'Three essays on the theory of sexuality', in idem, Standard Edition, op. cit. (note 43), Vol. 7 (1953), 123-243: 176.

92 'Gesetzmäßigkeit eines Sexualtriebes in der Kindheit', Freud, 'Drei Abhandlungen', op. cit. (note 6), 81; translation idem, 'Three Essays', op. cit. (note 91), 173.

93 Albert Moll, Ein Leben als Arzt der Seele: Erinnerungen (Dresden: Reissner, 1936), 146. 
exactly this early period of infanthood, arguing that this period had been often perceived as generally asexual because amnesia made everyone forget early sexual experiences. ${ }^{94}$

Skilfully creating a new genealogy, Freud claimed in 1905 that he had already emphasised the significance of childhood 'in the origin of certain important phenomena connected with sexual life' in his paper 'Ätiologie der Hysterie' in 1896, a year before Moll's book on the Libido sexualis. ${ }^{95}$ However, as explained above, Freud understood childhood sexuality at that time entirely in the context of pathology and neurosis. Indeed, in 1896, he merely speculated about whether one needed to trace back the causes of hysteria to the period of earliest childhood, an age he at that time described as 'a period before the development of sexual life'. ${ }^{96}$

The challenge Freud initially had been struggling with was to determine which activities of infants and children could be seen as of a sexual nature, and how to research the emerging first sexual feelings, which most people cannot remember owing to what he described as 'infantile amnesia'. ${ }^{97}$ In the Three Essays on the Theory of Sexuality, he suggested three main characteristics of infantile sexuality: they followed other vital bodily functions (eg. eating); they were not yet focused on a sexual object, and hence 'autoerotic'; and they were governed by an erogenous zone. ${ }^{98}$ Freud, like Moll and others, for instance, perceived the often rhythmical sucking of the lips (Lutschen or Ludeln) on any part of skin (eg. the thumb) or mucous membrane as a sexual activity (with the lips turned into an erogenous zone) that was initiated by an earlier experience of lust developed during breastfeeding. The previous satisfaction of hunger was now replaced by sexual satisfaction. ${ }^{99}$ But other body regions - he mentioned the anal region and the genitals - could also turn into erogenous zones in infants and be used by them to achieve sexual satisfaction. ${ }^{100}$ Further sources of sexual stimulation in infants and children included rhythmic mechanical vibrations, intensive muscular activities, any affective processes or mental strain. ${ }^{101}$

Freud now took the view that 'scarcely a single individual' would escape masturbation, and even suggested that genital masturbation by infants was invented by 'nature' to establish the primacy of the genitals as an erogenous zone for adult sexuality. ${ }^{102} \mathrm{He}$ distinguished three different phases of masturbation - and, normally, periods of nonmasturbation between them - with the first phase during early infanthood, the second around the age of four, and the third one during puberty. The second phase, described by Freud as the 'heyday of sexual activity' in children, was the most significant one for

\footnotetext{
${ }^{94}$ Freud, 'Drei Abhandlungen', op. cit. (note 6), 82-4.

95 'für die Entstehung gewisser wichtiger, vom Geschlechtsleben abhängiger Phänomene', ibid., 84; translation idem, 'Three Essays', op. cit. (note 91), 176.

96 Freud, 'Ätiologie der Hysterie', op. cit. (note 41), 63; English translation idem, 'The Aetiology of Hysteria (1896)', in idem, Standard Edition, op. cit. (note 43), Vol. 3 (1962), 187-221: 202.

${ }^{97}$ Freud, 'Drei Abhandlungen', op. cit. (note 6), 82-4, 87.

98 Ibid., 89.

${ }^{99}$ Freud acknowledged Lindner's article from 1879 [op. cit. (note 35)] but criticised Moll's interpretation of thumb sucking; Freud, 'Drei Abhandlungen', op. cit. (note 6), 87-9.

${ }^{100}$ Ibid., 90-5.

101 Ibid., 106-09.

102 Ibid., 94 (note 1); translation Freud, 'Three Essays', op. cit. (note 91), 188 (note 1); Freud removed the reference to nature in later editions of the essays as he had been criticised for its teleological implication. See also Sulloway, op. cit. (note 5), 435-6. In his copy of Moll's book, Freud had annotated the paragraph where the relevance of childhood play as an adaptive 'pre-activity' for the sexual drive in adulthood was explained; see Moll, op. cit. (note 51), in The Freud Museum, London (shelfmark 1378), 44.
} 
him, because sexual activities would make the 'deepest (unconscious) impressions in the subject's memory' and determine the future development of a person's character: whether they would develop neurotic symptoms after puberty, for instance, or stay mentally healthy. Freud thought that seduction by adults or other children could cause this return of early infant masturbation, but it could also occur as a spontaneous revival triggered by internal causes. ${ }^{103}$ These young children might also show some sexual interest in other people; for instance, when exhibiting their genitalia or showing curiosity in seeing other people's genitalia. ${ }^{104}$ In a section that he added in the revised 1915 edition, summarising a paper he had published previously, ${ }^{105}$ Freud elaborated further on this period, discussing the infantile drive to knowledge (Wißtrieb) and ensuing activities of sexual exploration (infantile Sexualforschung). The infant's sexual curiosity could be triggered by the arrival of a new sibling or by witnessing intercourse between his/her parents. Infantile sexual explorations shaped children's sexual knowledge in an important way, and, as Freud believed, were their first major step in achieving orientation in the world. ${ }^{106}$

The main difference between Freud's understanding of infant and childhood sexuality and that of most other researchers of the nineteenth and early twentieth century, including Moll and Ellis, was that Freud conceptualised infant sexuality in a much broader sense. ${ }^{107}$ This allowed him to understand infant behaviour, such as oral (eg. sucking) or analorientated activities (eg. restraint and release of excrement), as sexually driven. Moll, in contrast, rejected such a broad understanding of infant sexuality. ${ }^{108}$ Instead, he, and other researchers such as Ellis, had been looking for sexual behaviour (eg. masturbation or coitus) signs of sexual arousal (such as erection or orgasm), and social phenomena (such as being in love or jealous) in children that were similar to those of adults. These researchers were convinced that children would show all the sexual phenomena one would find in adults, and explained them as preparing children for adulthood or, in Moll's terminology, as a Vorahmung (see above). Whereas those who followed Moll's approach thought more in terms of sexual activities and reactions, psychoanalysts were emphasising meanings and relationships with the intention of differentiating between children's and adults' experiences. However, in their interpretation of children's sexual experiences, psychoanalysts continued to use an adult understanding of sexuality.

\section{The Sexualised Child of the Fin-de-Siecle}

Freud had developed his broader understanding of infant and childhood sexuality within the cultural context of fin-de-siècle Vienna characterised by a public furore over images of nude children and adolescent girls and boys in art and their representation in literature

103 ،... die tiefsten (unbewußten) Eindrucksspuren im Gedächnis der Person...', Freud, 'Drei Abhandlungen', op. cit. (note 6), 95-7: 95; translation idem, 'Three Essays', op. cit. (note 91), 189-91: 189.

${ }^{104}$ Freud, 'Drei Abhandlungen', ibid., 97-8.

105 Sigmund Freud, 'Über infantile Sexualtheorien (1908)', in idem, Studienausgabe, op. cit. (note 6), 169-84; also in idem, Gesammelte Werke, op. cit. (note 6), Vol. 7 (London: Imago, 1941), 171-88.

106 Freud, 'Drei Abhandlungen', op. cit. (note 6), 100-2.

107 Sigmund Freud, 'Die infantile Genitalorganisation: (Eine Einschaltung in die Sexualtheorie) (1923)', in idem, Studienausgabe, op. cit. (note 6), 235-41: 237; also in idem, Gesammelte Werk, op. cit. (note 6), Vol. 13 (London: Imago, 1940), 293-8.

108 Albert Moll, Das Sexualleben des Kindes (Berlin: Walther, 1909), 13. The distinction between Moll's narrower and Freud's much wider definitions of sexuality was already noted by some contemporary reviewers, eg. L. B., The Journal of Nervous and Mental Disease, 42 (1915), 719-20: 719. 
on the one hand, and the phenomenon of widespread under-age prostitution on Vienna's streets on the other. ${ }^{109}$

Around 1900, Viennese avant-garde artists, such as the Secessionists Gustav Klimt (1862-1918) and Oskar Kokoschka (1886-1980), as well as Anton Kolig (1886-1950) and later Egon Schiele (1890-1918), were preoccupied with the naked body, and produced a large corpus of drawings and paintings portraying the (pre-) pubescent nude bodies of boys and girls. ${ }^{110}$ Many of these images were clearly of an erotic nature, depicting, for instance, young women and men masturbating. Large sections of the Viennese intellectual elite, including the novelist and dramatist Arthur Schnitzler (1862-1931), ${ }^{111}$ the 'coffeehousepoet' Peter Altenberg (1859-1919), ${ }^{112}$ the satirist and editor of Die Fackel Karl Kraus (1874-1936), the writer, physician and psychoanalyst Fritz Wittels (1880-1950), ${ }^{113}$ and the modernist architect and castigator of all ornamentation Adolf Loos (1870-1933), ${ }^{114}$ were smitten by erotic fantasies about the 'child-woman' (Kindsweib), and fought over the affection of young actresses, ballet dancers or models. In his obituary on Altenberg, Alfred Kerr (1867-1948), one of the leading German theatre critics, concluded '(Y)our coffin should have been carried only by fifteen-year-old girls'. ${ }^{115}$

${ }^{109}$ Nike Wagner, Geist und Geschlecht: Karl Kraus und die Erotik der Wiener Moderne (Frankfurt: Suhrkamp, 1981); Gilman, op. cit. (note 12), 41-2 on child prostitutes in Vienna.

${ }^{110}$ See, for instance, with numerous examples, the exhibition catalogue by Tobias Natter and Max Hollein (eds): Die nackte Wahrheit: Klimt, Schiele, Kokoschka und andere Skandale (Munich: Prestel, 2005); Patrick Werkner, 'The child-woman and hysteria: images of the female body in the art of Schiele, in Viennese modernism, and today', in idem (ed.), Egon Schiele: Art, Sexuality, and Viennese Modernism (Palo Alto: Society for the Promotion of Science and Scholarship, 1994), 51-78.

${ }^{111}$ Brenda Keiser, 'The "süßes Mädel” in Fin-de-Siècle and Modern Vienna', in Christiane Schönfeld (ed.), Commodities of Desire: The Prostitute in Modern German Literature (Rochester, NY: Camden House, 2000), $62-76$.

112 Altenberg not only wrote erotic sketches with young girls as the object of desire (eg. Peter Altenberg, 'Musik', in idem, Wie ich es sehe (Berlin: Fischer, 1896), 57). He also collected a large number of picture postcards and had photographs taken of young girls he favoured and admired, many of them in the nude and put on display on the walls of his room in the Grabenhotel where he lived. Hans Christian Kosler (ed.), Peter Altenberg: Leben und Werk in Texten und Bildern (Munich: Matthes \& Seitz, 1981), with images from Altenberg's collection; Werkner, op. cit. (note 110), 62, 64; Leo Lensing, 'Peter Altenberg's fabricated photographs: literature and photography in fin-de-siècle Vienna', in Edward Timms and Ritchie Robertson (eds), Vienna 1900: From Altenberg to Wittgenstein (Edinburgh: Edinburgh University Press, 1990), 47-72; Gilman, op. cit. (note 12), 48-50; Wolfgang Till, 'Zwei galante Sammler aus Wien: Anton Pachinger und Peter Altenberg', in Michael Köhler and Gisela Barche (eds), Das Aktfoto: Ansichten vom Körper im fotografischen Zeitalter: Ästhetik, Geschichte, Ideologie, rev. edn (Munich: Bucher, 1996), 285-8.

113 Wittels gained some prominence in Vienna with articles he published in Kraus' Die Fackel. He later fell out with Kraus when he began an affair with one of Kraus' girlfriends, the teenage actress Irma Karczewska, who became the archetype for the 'child-woman'. Fritz Wittels, Freud and the Child Woman: The Memoirs of Fritz Wittels, Edward Timms (ed.) (New Haven, CT: Yale University Press, 1995); Leo Lensing: " "Freud and the Child Woman” or "The Kraus Affair”? A Textual "Reconstruction” of Fritz Wittels's Psychoanalytic Autobiography', The German Quarterly, 69 (1996), 322-32; Edward Timms, 'The "Child-Woman”: Kraus, Freud, Wittels, and Irma Karczewska in Fin-de-Siècle Vienna', in Timms and Robertson (eds), ibid., 87-107.

${ }^{114}$ Loos commented in an essay in 1902, 'There was a call for youth. The child-woman came into fashion. There was thirst after immaturity.' Adolf Loos: 'Damenmode', Dokumente der Frauen, 6, 23 (1902), 660-4: 661-2 ('Der Ruf nach Jugend erscholl. Das Weibkind kam in Mode. Man lechzte nach Unreife.'). In 1928 he came into conflict with the law when he was accused of sexually molesting and abusing underage girls in the Vienna Forest; Werkner, op. cit. (note 110), 62, 64, 66-8; Klaralinda Ma: 'Der 'Fall”' Loos', in Inge Podbrecky and Rainald Franz (eds), Leben mit Loos (Vienna, Cologne \& Weimar: Böhlau, 2008) 161-72.

115 'Lauter fünfzehnjährige Mädel hätten Deinen Sarg tragen sollen.' Alfred Kerr, 'Dem toten Peter Altenberg', Die Neue Rundschau, 30 (1919), 329-35: 335. 
The theoretical foundation for the 'child-women' was provided by Fritz Wittels in 1907 in an article in Kraus' Die Fackel, which he wrote under the pseudonym 'Avicenna'. With the 'child-woman' Wittels praised the sexually precocious, young and beautiful girl who, child-like and behind in her intellectual development, was as an hetaera, prepared to engage in polygamous experiences. He saw the 'child-woman' as the equivalent to the male genius. Wittels assured his readers that such 'child-women' were not just a product of fantasy, like Wedekind's Lulu, but would exist in 'reality'. ${ }^{116}$ But Viennese intellectuals already knew this, because many of them were intimately engaged in promiscuous mishmashes or polygamous relationships with such 'child-women', including, for example, the teenage actress Irma Karczewska (b. c.1890). She had been discovered by Kraus and had been with him for a while before Wittels fell in love with her, but she also had relationships with other men. ${ }^{117}$

Avant-garde artists often enlisted children as models, which, in some cases, turned out to be contentious. In 1912, for instance, Egon Schiele was in court over allegations of immorality resulting from the display of two erotic drawings in the bedroom of his house in Neulengbach (near Vienna) where he lived with his then girlfriend, Wally Neuzil, because some of the local children who had visited him had seen these pictures. Even more serious was the accusation that Schiele, who was twenty-two years of age at the time, had abducted and sexually abused a girl younger than fourteen who had stayed with him overnight. Furthermore, the locals had reported that they had watched Schiele handing out oranges to children in front of the local school. Many children were seen coming to his house, and the children later mentioned that the artist had often drawn them in the nude. The police searched Schiele's premises and confiscated 125 drawings, one of which the court later ordered to be destroyed. Schiele was taken into custody for twenty-one days and later sentenced to an additional three days of imprisonment for distributing indecent images. The judge acquitted him of the other allegations. Despite this threatening experience, Schiele continued to produce numerous erotic drawings and paintings of adolescent girls and young women, some of them very explicit. ${ }^{118}$

This eroticisation and sexualisation of children, in particular of girls, went beyond Vienna's intellectual and artistic world, and can also be traced in contemporary pornography; for instance, in 1906, one year after Freud's Three Essays, the novel Josefine Mutzenbacher, or the History of a Viennese Whore as Told by Herself was published. The novel tells, in very explicit and graphic detail, the story of Josefine Mutzenbacher, who was born into a poor Viennese working-class family, how she grew up and became a prostitute, and died in 1904. ${ }^{119}$ The narrative begins when Josefine, aged five, was sexually molested by a boarder; she first participated in sexual activities at the age of seven in an encounter with two sexually experienced children, a brother and sister aged thirteen and nine respectively, to whom she was introduced by her brother Franz. ${ }^{120}$ Starting as

\footnotetext{
116 Avicenna (ie. Fritz Wittels), 'Das Kindweib', Die Fackel, 9, 230-1 (15 July 1907), 14-33: 14.

117 Wittels, op. cit. (note 113), ch. 5; Lensing, op. cit. (note 113); Timms, 'Child-Woman', op. cit. (note 113); Wagner, op. cit. (note 109), 134-6.

118 Tobias Natter, 'Über die Grenzen des Ausstellbaren - Das Nackte und das Öffentliche in der Wiener Kunst um 1900', in Natter and Hollein (eds), op. cit. (note 110), 17-41: 38-41; Werkner, op. cit. (note 110), 68.

119 Josefine Mutzenbacher, Die Lebensgeschichte einer wienerischen Dirne, von ihr selbst erzählt (Reinbek: Rowohlt, 1978) (first, Vienna: Fritz Freund, 1906). It is not clear who the author was, but Felix Salten (1869-1945), the author of Bambi, has been alleged to have written the novel, although he had denied this. See K.H. Kramberg, 'Vorbemerkung', in Mutzenbacher, ibid., 5-6; Gilman, op. cit. (note 12), 44-8.

${ }^{120}$ Mutzenbacher, ibid., 8-12.
} 
a mother-father-baby game, the four children soon began to touch each other sexually; their activities eventually led to sexual intercourse or at least the attempt of it. Josefine concluded from this experience: 'I was only seven years old but my sexuality had fully emerged', although she was not yet capable of full intercourse. ${ }^{121}$ The initially seduced little girl now turned into the seducer, the whore, whom the novel portrayed as a girl who enjoyed sex in every respect, thereby completely ignoring the horrors of child prostitution. The novel represented children's sexual experiences as analogous to the sexuality of adults. $^{122}$

Neither the erotic fantasies of the 'child-woman' described by the Viennese avantgarde, nor her representation in pornographic novels, were isolated instances. As Sander Gilman illustrated, erotic depictions of young children can also be found in Thomas Mann's Death in Venice (1912), in Felix Salten's comments on photographs from Vienna's Prater - published in 1911, in Arthur Schnitzler's writing (Casanova's Return Home, 1918) as well as in that of Hugo von Hoffmannsthal (Lucidor, 1910). ${ }^{123}$ Other examples of such an interest in the prepubescent child can be found, for instance, in the works of numerous Victorian artists, photographers and writers in Britain and elsewhere. ${ }^{124}$

\section{Albert Moll's Sexual Life of the Child}

It is not yet entirely clear exactly how Moll's thinking in Berlin was shaped by this wider cultural context that sexualised the child. However, like Vienna, fin-de-siècle Berlin was a hotbed of modernity and abundant discussions about sexuality, not only amongst experts but also within the intellectual elite and the wider public. Conversations in coffee-houses and pubs and countless articles in local and national newspapers discussed sexual morality and public nudity, venereal diseases and (child) prostitution, homosexuality, sex scandals and the sexual abuse of children. ${ }^{125}$ For example, the case of the Berlin bank director and multimillionaire August Sternberg received an enormous amount of public attention.

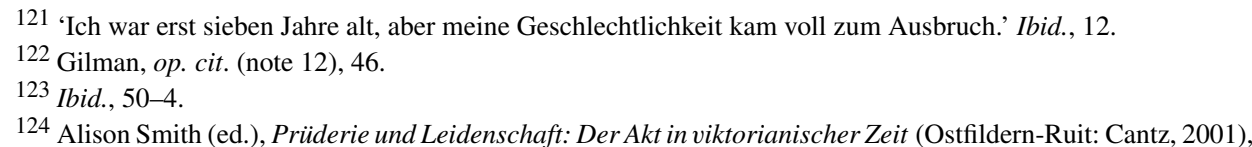
166-8, 178, 251, 262, 268-75, and 278-9; Claudia Nelson, 'That Other Eden: Adult Education and Youthful Sexuality in "The Pearl”, 1879-1880', in Claudia Nelson and Michelle Martin (eds), Sexual Pedagogies: Sex Education in Britain, Australia, and America, 1879-2000 (Basingstoke: Palgrave Macmillan, 2004), 15-32; Sally Shuttleworth, The Mind of the Child: Child Development in Literature, Science, and Medicine, 1840-1900 (Oxford: Oxford University Press, 2010), 213-20. One of the most famous examples was Charles Lutwidge Dodgson (Lewis Carroll) and his fascination with young girls, whom he photographed in the nude from the late 1860s. Researchers on Carroll are much divided about how to interpret Carroll's photographs. Some scholars (eg. Morton Cohen) defend them as representations of innocence and others, such as art historian Carol Mavor, emphasise their sexual nature; Morton Cohen, Lewis Carroll, Photographer of Children: Four Nude Studies (New York: Potter, 1978), 5-6; Carol Mavor, 'Dream-rushes: Lewis Carroll's photographs of the Little Girl', in Claudia Nelson and Lynne Vallone (eds), The Girl's Own: Cultural Histories of the Anglo-American Girl, 1830-1915 (Athens and London: University of Georgia Press, 1994), 156-93.

125 Lutz Sauerteig, Krankheit, Sexualitat, Gesellschaft: Geschlechtskrankheiten und Gesundheitspolitik in Deutschland im 19. und frühen 20. Jahrhundert (Stuttgart: Steiner, 1999); Dorothy Rowe, Representing Berlin: Sexuality and the City in Imperial and Weimar Germany (Aldershot: Ashgate, 2003); Joachim Schlör, Nights in the Big City: Paris, Berlin, London 1840-1930, P.G. Imhof and D.R. Roberts (trans.) (London: Reaktion, 1998) ch. IV; Ulfried Geuter, Homosexualität in der deutschen Jugendbewegung. Jugendfreundschaft und Sexualität im Diskurs von Jugendbewegung, Psychoanalyse und Jugendpsychologie am Beginn des 20. Jahrhunderts (Frankfurt: Suhrkamp, 1994); Maren Möhring, Marmorleiber: Körperbildung in der deutschen Nacktkultur (1890-1930) (Cologne: Böhlau, 2004); Karl Toepfer, Empire of Ecstasy: Nudity and Movement in German Body Culture, 1910-1935 (Berkeley: University of California Press, 1997); Frank Bösch, 'Das Private wird 
Married and in his mid-forties, he had been accused of sexually abusing underage girls over many years. After avoiding prosecution for nearly two decades by bribing police officers, potential witnesses and journalists, Sternberg was arrested in January 1900 and brought to court. Albert Moll was one of the expert witnesses advising the court about the credibility of a key witness, a girl of about 12 years. Although Moll conceded that the defendant certainly had a 'proneness to immature girls', he came to the conclusion that the young witness could not be trusted because she was sexually precocious, had a strong sexual imagination and made contradictory statements. The court, however, disagreed and believed the girl's first statement in which she had incriminated the defendant. In December 1900, Sternberg was convicted and sentenced to two and a half years of imprisonment (in a Zuchthaus) and the loss his of civil rights (Ehrverlust) for five years. Moll, however, remained convinced that Sternberg was wrongfully convicted. ${ }^{126}$

In this context of public interest in sexuality and scandals Moll's 1908 study Das Sexualleben des Kindes [The Sexual Life of the Child] was widely reviewed and reported with great acclaim in the national and international academic press. ${ }^{127}$ Many reviewers acknowledged that it was the first comprehensive scientific account of childhood sexuality. ${ }^{128}$ Pedagogue Konrad Agahd (1867-1926) and philosopher Walter Kühne praised Moll's book highly and recommended it for any teacher's library, and to any other learned person. ${ }^{129}$ For Cologne-based dermato-venereologist Emil Meirowsky (1876-1960), the book filled 'a gap, since hitherto we did not have such a comprehensive and elaborate account of every aspect of the sexual life of the child'. ${ }^{130}$ Some reviewers, including the eminent psychiatrist, sexologist and criminalist Paul Näcke (1851-1913), clearly sided with Moll against Freud. ${ }^{131}$ Robert Müller (1866-1922), a professor of

politisch. Die Sexualität des Politikers und die Massenmedien des ausgehenden 19. Jahrhunderts', Zeitschrift für Geschichtswissenschaft, 52 (2004), 781-801; Kerchner, op. cit. (note 29).

${ }^{126}$ Moll, op. cit. (note 93), 174-7: 175; idem, op. cit. (note 108), 183-4; Hugo Friedländer, Interessante Kriminal-Prozesse von kulturhistorischer Bedeutung. Darstellung merkwürdiger Strafrechtsfälle aus Gegenwart und Jüngstvergangenheit, 11 vols, Vol. 2 (Berlin: Barsdorf, 1911), 229-319.

127 Moll, op. cit. (note 108); there is an earlier edition of Das Sexualleben des Kindes (Leipzig: Vogel, 1908). In 1912, Moll's book was translated into English: idem, The Sexual Life of the Child, E. Paul (trans.) (London: Allen, 1912), repr. 1929.

128 See, for example, (Oscar) Rie, Wiener klinische Rundschau, 22 (1908), 796-7; James Heymann, Zeitschrift für pädagogische Psychologie, Pathologie und Hygiene, 10 (1908/09), 358-65; Saenger, Das Schulzimmer, 7, 2 (1909), 132-3; Pädagogische Zeitung, Literarische Beilage, 34, 5 (1909), 29; (Friedrich) Siebert, Münchener Medizinische Wochenschrift, 56, 20 (1909), 1029-30; Karl Gumpertz, Deutsche Medizinische Presse, 13, 20 (1909), 157; Otto Adler, Geschlecht und Gesellschaft, 4 (1909), 442-53; Fürstenheim, Jahrbuch für Kinderheilkunde und physische Erziehung, 60 (1909), 372-4; Grätzer, Zentralblatt für Kinderheilkunde, 14 (1909), 83; (Wilhelm) Wechselmann, Sexual-Probleme, 5 (1909), 59-61; (Karl) Abraham, Centralblatt für Nervenheilkunde und Psychiatrie, 32 (1909), 446; Bs., Zeitschrift für Krüppelfürsorge, 2 (1909/10), 138-9; Numa Praetorius (Eugen Daniel Wilhelm), Jahrbuch für sexuelle Zwischenstufen, 1 (=10) (1909/10), 87-93; Karl Wilker, Die Neue Generation, 6 (1910), 167-9; Ernst Levy, Zeitschrift für pädagogische Psychologie und experimentelle Pädagogik, 12 (1911), 493-4; Die höhere Mädchenschule, 25 (1912), 149; W.C.B. (William Chandler Bagley), Journal of Educational Psychology, 4 (1913), 102-3. Reports in Archiv für Kinderheilkunde, 49 (1909), 464; Deutsche Medizinische Wochenschrift, 36 (1910), 862-3; Die höhere Mädchenschule, 25 (1912), 149; American Journal of Psychology, 24 (1913), 285; American Journal of Medical Sciences, 147 (1914), 753.

${ }^{129}$ Konrad Agahd and Walter Kühne, Die Kinderfehler, 14 (1909), 253-6.

130 '[F]üllt... eine Lücke aus, da wir bisher eine so umfangreiche und ausführliche Darstellung aller Erscheinungen des sexuellen Lebens des Kindes nicht besitzen.' (Emil) Meirowsky, Zeitschrift für Bekämpfung der Geschlechtskrankheiten, 10 (1909/10), 255.

${ }^{131} \mathrm{P}$ (aul) Näcke, Archiv für Kriminal-Anthropologie und Kriminalistik, 21 (1911), 165; Näcke, however, disagreed with Moll's view on homosexuality and instead supported Hirschfeld. 
livestock breeding from Dresden, referred, in the section on childhood sexuality in his 1907 book Sexualbiologie, only to Albert Moll and not to Freud. ${ }^{132}$

A small number of reviewers took a more critical stance. A British reviewer, for instance, remarked that Moll focused too much on 'exceptional and pathological cases' of childhood sexuality, and therefore believed the volume to be 'somewhat unsatisfactory' and Moll's perspective 'wrong'. ${ }^{133}$ British reviewers also noticed with approval that the sale of the English translation was restricted to the 'medical, scholastic, legal, and clerical professions' as the book was 'certainly not suited for any one else'. ${ }^{134}$ Only very few reviews were as scathing as the one by a paediatrician from Breslau, who disputed not only Moll's expertise in this field, but urged sexologists in general to restrict themselves to adult sexuality and stay away from childhood. ${ }^{135}$

Despite this wide-ranging resonance in national and international academia, Moll's book failed to make a long-term impact. Although his extensive volume dealt with numerous aspects of young people's sexual development and gave a very detailed and nuanced account of his observations, the fundamental principles remained very much the same as he had outlined ten years earlier. The Sexual Life of the Child was rich in detail and came with a plethora of case studies to substantiate his claims, but Moll failed to take the research agenda intellectually any further.

On the basis of his distinction between the detumescence-impulse and the contrectationimpulse, he explained the physical signs (eg. erection and ejaculation) as well as the psychological symptoms (eg. love, jealousy, shame) of childhood sexuality, and gave many examples of children's sexual activities, including masturbation. ${ }^{136}$ His discussion of manifestations of the contrectation-impulse in childhood, however, did not reveal any new aspects but, like his description of the detumescence-impulse, was more detailed in his observations about children. He rejected the claims of the American psychologist Sanford Bell, who suggested that infants as young as two years old would show psychosexual symptoms. Moll thought these claims were not sufficiently substantiated in their sexual basis. ${ }^{137} \mathrm{He}$ agreed, however, that as children grew older one could observe more frequent psychosexual phenomena. Eventually, in children aged eight, manifestations of the contrectation-impulse became so frequent that, as Moll concluded, they were no longer either pathological or abnormal. ${ }^{138}$

With rare clarity, Moll repeated one of his main claims that many children who had experienced homosexual activities in childhood would later in life show a 'normal', that is, heterosexual orientation. 'During puberty, usually the normal [heterosexual] becomes predominant. The undifferentiated psyche during childhood allows us to understand, that such contrary sexual [ie. homosexual] tendencies of the child do not necessarily indicate a permanent contrary sexual character later or its subsequent development. ${ }^{139}$

\footnotetext{
132 Robert Müller, Sexualbiologie: Vergleichend-entwicklungsgeschichtliche Studien über das Geschlechtsleben des Menschen und der höheren Tiere (Berlin: Marcus, 1907); see Sulloway, op. cit. (note 5), 431.

133 John Edgar, Mind, N.S. 22 (1913), 299-301: 300.

134 The Athenaeum (London), 4428 (7 September 1912), 250.

135 Birk, Monatsschrift für Kinderheilkunde, 8 (1909), 50-1.

${ }^{136}$ Moll, op. cit. (note 108), 46-102.

${ }^{137}$ Moll referred here to Sanford Bell, 'A Preliminary Study of the Emotion of Love Between the Sexes', The American Journal of Psychology, 13, 2 (1902), 325-54. Bell had been a student of G. Stanley Hall (cf. above note 10), at Clark University where Freud received an honorary doctorate in 1909.

138 Moll, op. cit. (note 108), 63.

139 'In der sogenannten Entwicklungszeit bricht dann gewöhnlich das Normale durch. Die Undifferenziertheit des Seelenlebens in der Kindheit lässt es verstehen, dass nicht ohne weitres solche konträr sexuellen Neigungen
} 
He also hammered home his central point 'that sexual manifestations in childhood are not necessarily to be regarded as pathological.' ${ }^{140}$ Only cases of infants and very young children who showed signs of sexual drive under the age of eight remained, in his eyes, suspicious of an existing pathological predisposition. ${ }^{141}$ Thus, it was around the age of eight where Moll drew the line between pathological and normal childhood sexuality. Consequently, he did not perceive erections in baby boys as being of a sexual nature. ${ }^{142}$

This is where Moll differed from Freud's assertions in his Three Essays on the Theory of Sexuality: 'But what he [Freud] mentions and describes as symptoms of infantile sexuality, eg. certain sucking movements, has, in my opinion, nothing to do with the sexual life of the child.... ${ }^{143} \mathrm{He}$ also doubted that rocking movements of babies and infants could be understood as an indication of masturbation. In his view they were most of the time expressions of a general sense of comfort (Behagen). Nevertheless, he admitted that there were rare occasions when even infants would show clear signs of experiencing a 'voluptuous sensation' (Wollustempfindung), however usually without the 'voluptuous acme' (Wollustakme) of an orgasm. As his careful phrasing indicated, he seemed to acknowledge that, in rare cases, babies, and children aged seven to eight, have experienced an orgasm. Yet, Moll believed that most children would not have had such an experience, but a more constant voluptuous feeling. ${ }^{144}$

Thus, although Moll acknowledged Freud's concept of infantile sexuality, he sharply rejected Freud's psychoanalytical theory of childhood sexuality, and was far more cautious about the limits of what could be perceived as sexual behaviour in children. Moll warned over and over again that one should 'carefully limit the sexual life of the child'. ${ }^{145} \mathrm{He}$ also dismissed Freud's claim about the sexual nature of neuroses and concluded: 'In any case, Freud has not systematically studied the individual manifestations of the sexual life of the child.' ${ }^{146}$

\section{Contested Concepts of Childhood Sexuality}

But it was not only Moll who attacked Freud over his understanding of infant and childhood sexuality. Within the psychoanalytical movement, a fundamental critique came from C.G. Jung in Zurich, one of Freud's closest supporters and 'the principal architect of the psychoanalytic movement'. ${ }^{147}$ Jung voiced his critical comments in a lecture

des Kindes auf das spätre dauernde Bestehenbleiben und die weitre Entwicklung konträr sexueller Eigenschaften hinweisen'. Moll, ibid., 113; idem, op. cit. (note 127), 126 (my own translation).

140 '[D]ass sexuelle Erscheinungen in der Kindheit an sich nicht pathologisch sind', Moll, op. cit. (note 108), 131; idem, op. cit. (note 127), 146.

${ }^{141}$ Moll, op. cit. (note 108), 133.

142 Ibid., 153.

143 'Was er aber darüber bringt und als Symptome infantiler Sexualität schildert. . hat meiner Meinung nach mit dem Geschlechtsleben des Kindes nicht zu tun...', Moll, op. cit. (note 108), 13; translation, slightly rephrased, idem, op. cit. (note 127), 14. Moll repeated his criticism of Freud several times throughout his study, see, for example, idem, op. cit. (note 108), 154; Freud, 'Drei Abhandlungen', op. cit. (note 6), 87-9, had followed Lindner [op. cit. (note 35)], whose claims Moll rejected in op. cit. (note 108), 155.

144 Moll, op. cit. (note 108), 53-4.

145 'Ueberhaupt tun wir gut, das Sexualleben des Kindes vorsichtig zu begrenzen'. Ibid., 156-8, 161: 156.

146 'Jedenfalls hat Freud nicht in systematischer Weise die einzelnen Aeusserungen des Sexuallebens beim Kinde untersucht'. Ibid., 13; Moll, op. cit. (note 127), 14. See Moll's critique of Freud's seduction theory and his theory of the sexual aetiology of neuroses, Moll, op. cit. (note 108), 171-3.

147 Sonu Shamdasani, Jung and the Making of Modern Psychology: The Dream of a Science (Cambridge: Cambridge University Press, 2003), 2; from a Freudian perspective, Peter Gay, Freud: A Life for our Time (1988) (repr. London: Max, 2006), 197-206 and 218-43. 
series he gave at Fordham University in New York in the autumn of 1912. His latent disagreement with Freud had become obvious in the previous year when Jung had published his own views opposing Freud's libido theory. Jung believed that this was too much centred on sexuality. In a direct attack, Jung accused Freud and his fellow psychoanalysts of 'projecting an observation from adult life onto the child's mind' ${ }^{148}$ Rather than interpreting thumb sucking as a sexual practice related to the emerging sexual libido, Jung understood it as entirely unrelated to anything sexual; in his view it was a nutritive practice. ${ }^{149}$ According to Jung's definition of libido, the 'hunger libido' in infancy only slowly changed its character and function during childhood, turning into a sexual libido when the child discovered masturbation. Although Jung agreed with Freud over a link between the nutritive and sexual function of libido, Jung saw libido as a form of energy that changed its function during childhood. He perceived early infancy as a 'pre-sexual phase' that was characterised by developmental and nutritional functions and not, as Freud believed, by any sexual libido. ${ }^{150}$ Consequently, Jung rejected Freud's notion of the polymorphic perverse sexuality of children. For Jung, there was nothing 'perverse' in infants' libido because libido at that stage was entirely driven by its nutritive function. 'Perversions are disruptive products of the developed sexuality, but never a pre-stage of sexuality,' he argued. ${ }^{151}$ First signs of sexuality would develop during what Jung defined as the pre-pubertal phase, beginning around the age of three to five. By the end of this phase, libido eventually would be stripped of all the characteristics and functions it showed during early infancy. Perversions, then, would be the consequence of an incomplete or disrupted change of function in libido. ${ }^{152}$ Jung's intervention was of great importance and posed a threat to the psychoanalytical movement because he offered a libido theory that was more acceptable to general psychology and psychotherapy. ${ }^{153}$ Jung's differences with Freud finally led to the breakup between them in 1913; Jung resigned as president of the International Psychoanalytical Association, leaving the psychoanalytical movement behind and moving on to develop his new system of analytical psychology.

Most psychologists had rejected Freudian psychoanalysis until this point. In a polemical and intellectually sharp analysis, William Stern, for instance, professor of psychology at Breslau University and at the time more prominent than Freud, ${ }^{154}$ criticised the application of psychoanalytical theories to infants and children. He accused psychoanalysts of going

\footnotetext{
148 ‘... eine Konstatierung aus dem Leben des Erwachsenen in die Seele des Kindes projizieren'. Carl Gustav Jung, 'Versuch einer Darstellung der psychoanalytischen Theorie', in idem (ed.), Gesammelte Werke, Vol. 4: Freud und die Psychoanalyse (Zurich and Stuttgart: Rascher, 1969), 107-255: 131; first published in Jahrbuch für psychoanalytische und psychopathologische Forschungen, 5 (1913). On Jung's libido theory, see Shamdasani, ibid., 210-13, 220-30 and 243-51; George Makari, Revolution in Mind: The Creation of Psychoanalysis (New York: Harper Collins, 2008), 267-79.

149 Jung, ibid., 128-31. A similar point was made by Eugen Bleuler, Jung's former chief, in 1912, although he thought Jung had gone too far in de-sexualising libido. Bleuler saw himself standing somewhere between Freud and Jung in this respect but leaning more towards Freud; Shamdasani, ibid., 224-5.

${ }^{150}$ Jung, ibid., 141, 152-3. In a later lecture on the Oedipus complex, Jung slightly rephrased his claim stating that in early infanthood the sexual element is 'evanescent (verschwindend) small', ibid., 179.

151 'Perversitäten sind Störprodukte der ausgebildeten Sexualität, aber niemals die Vorstufen der Sexualität... ', ibid., 153.

152 Ibid., 142.

153 Shamdasani, op. cit. (note 147), 226.

${ }^{154}$ Gerald Bühring, William Stern oder Streben nach Einheit (Frankfurt: Lang, 1996). On the strained relationship between Stern and Freud and other psychoanalysts, ibid., 64-79; Angela Graf-Nold, 'Stern versus Freud: Die Kontroverse um die Kinder-Psychoanalyse. Vorgeschichte und Folgen', in Werner Deutsch (ed.), Über die verborgene Aktualität von William Stern (Frankfurt: Lang, 1991), 49-91; Peter Dudek, Jugend als Objekt
} 
much too far by detecting something sexual everywhere and in everyone. 'What they perceive as a common characteristic of all human beings, would in reality only apply to a specific psychological type,' he argued. ${ }^{155}$ What infuriated Stern most was the application of psychoanalytical theories to children. He was outraged by what he described as 'exaggeration and generalisation of that principle of child sexuality', in particular, its application to ever-younger children, even to new-born babies. ${ }^{156}$ Psychoanalysis would harm children tremendously by making conscious in them what should remain unconscious. This would lead to, as he called it, an Entharmlosung of sexuality (making sexuality not harmless or innocent) in the young. Stern accused psychoanalysis of inducing a 'sultry, precocious sexual consciousness' in children and, through the power of suggestion, 'psycho-sexually infecting' them. ${ }^{157}$ In other words, psychoanalysis would sexualise the child whose sexuality was still unconscious. If a child showed signs of precocious sexual interests, Stern considered this pathological. In his practice as a psychologist who had observed and worked with many children, including his own, Stern never discovered 'the faintest trace of a sexual undertone in the memory' of children. ${ }^{158}$

Likewise, Karl Kraus, who initially took an interest in Freud's theories, occasionally attending his lectures at Vienna University and corresponding with him, became increasingly sceptical over key psychoanalytical assumptions and theories. Like Jung and Stern, Kraus suspected that much of psychoanalysis was based on projections. In 1908, Kraus broke with Freud - the immediate reason was the conflict with Wittels $-{ }^{159}$ and from then on, commented with biting irony on the psychoanalytical movement. This culminated in his aphorism that 'Psychoanalysis is that mental illness of which it regards itself as therapy.' 160

In the late 1920s and early 1930s, Charlotte Bühler, professor of psychology at the University of Vienna, launched an even more fundamental and detailed attack on Freud's claims about infant and childhood sexuality. ${ }^{161}$ Bühler became a leading developmental psychologist and helped to establish the new research direction for child and youth studies that was based on a close and systematic scientific observation of children. She criticised the fact that psychoanalysis ignored serious methodological problems when exploring infant and childhood sexual experiences, because one could not draw any analogies between their experiences and those of adults. This was exactly what, in her view,

der Wissenschaften: Geschichte der Jugendforschung in Deutschland und Österreich 1890-1933 (Opladen: Westdeutscher Verlag, 1990), 111-13.

155 'Sie halten das für eine allgemeine Eigenschaft der Menschen, was in Wirklichkeit höchstens einem bestimmten psychologischen Typus zukommt', William Stern, 'Die Anwendung der Psychoanalyse auf Kindheit und Jugend. Ein Protest. Mit einem Anhang: Kritik einer Freudschen Kindes-Psychoanalyse, von Clara und William Stern', Zeitschrift für angewandte Psychologie und psychologische Sammelforschung, 8 (1913/4), 71-101: 73.

156 Ibid., 76.

157 Ibid., 77-8; on the harm suggestions were causing, 94-7.

158 Ibid., 86-7; Bühring, op. cit. (note 154), 72-3.

159 Lensing, op. cit. (note 113).

160 'Psychoanalyse ist jene Geisteskrankheit, für deren Therapie sie sich hält.' Karl Kraus, (Aphorisms), Die Fackel, 15, 376 (30 May 1913), 21. On the relationship between Kraus and Freud, Wagner, op. cit. (note 109), 118-31.

161 Charlotte Bühler, 'Zum Problem der sexuellen Entwicklung', Zeitschrift für Kinderheilkunde, 51 (1931), 612-42; Charlotte Bühler, 'Zum Problem der sexuellen Entwicklung: Replik auf die kritischen Bemerkungen von J.K. Friedjung', Zeitschrift für Kinderheilkunde, 52 (1931/2), 295-8. On Bühler, see Gerald Bühring, Charlotte Bühler oder Der Lebenslauf als psychologisches Problem (Frankfurt: Lang, 2007). 
psychoanalysts were guilty of doing. ${ }^{162}$ Although she, in contrast to her Breslau colleague Stern, concurred in general with the claim of the existence of infant and childhood sexuality and about children having lustful experiences, she argued that their sexual experiences were completely distinct from those of adults. Therefore, sexual behaviour in children could not be interpreted from an adult perspective but had to be understood in its own right. This was also an implicit critique of Moll's interpretation of childhood sexuality. Furthermore, Bühler was not convinced that infants and children could have an orgasm (acme). Both masturbation in infancy and sexual activities between children were, in her view, neither common nor frequent. She explained the few such cases as pathological, thereby explicitly concurring with Moll's views in this respect. ${ }^{163}$ Rejecting any form of homology between adult and childhood sexuality, as implied by the psychoanalysts and also Moll, Bühler saw childhood sexuality as clearly different from adult sexuality.

\section{Albert Moll Eclipsed}

Freud and his fellow psychoanalysts did everything to defend their psychoanalytical understanding of infant and childhood sexuality. In November 1908, soon after Moll's book had been published, Freud reminded his colleagues at a meeting of the Wiener Psychoanalytische Vereinigung [Vienna Psychoanalytical Society] that it was he who had discovered 'normal infant sexuality'. Freud accused Moll of plagiarism, and described his book as an 'inadequate, inferior and above all dishonest book'. ${ }^{164}$ The following day, Freud repeated his attack against Moll in a letter to C.G. Jung, calling Moll 'a mean, malicious soul' and stating 'what a narrow mind he must have'. ${ }^{165}$ In May 1909, Moll paid Freud a visit when he was in Vienna. From both of their accounts, one gets a very good impression of how much they disliked each other. Moll accused Freud of being thinskinned and incapable of accepting criticism, and Freud described Moll as a 'brute' and 'not really a physician' but someone who 'has the intellectual and moral constitution of a pettifogging lawyer'. ${ }^{166}$ Subsequently, in the second edition of his Three Essays on the Theory of Sexuality, published in 1910, Freud even listed Moll under those authors who have ignored childhood sexuality; a damning judgement that other psychoanalysts were soon to follow, including Isidor Sadger (1867-c. 1942), who described Moll as a case of 'stultification through opposition' (Widerstandsverblödung). ${ }^{167}$

\footnotetext{
162 Bühler, 'Zum Problem', ibid., 613.

163 Ibid., 623-9; Bühler (ibid., 625) referred to Moll's book [op. cit. (note 108)].

164 '[U]nzulängliches, minderwertiges und vor allem als ein unredliches Buch', Herman Nunberg and Ernst Federn (eds), Protokolle der Wiener Psychoanalytischen Vereinigung, 4 vols, Vol. 2, 1908-1910 (Frankfurt: Fischer, 1977), minutes 58, 11 November 1908, 39-47: 43-4; Herman Nunberg and Ernst Federn (eds), Minutes of the Vienna Psychoanalytic Society, Vol. 2 (New York: International University Press, 1967), 43-52: 48. A few days before the meeting, Freud had made a similar negative comment in a letter to C.G. Jung calling Moll's book 'dishonest and incompetent', Sigmund Freud, '(Letter 112F to Jung, 8 November 1908)', in William McGuire (ed.), The Freud/Jung Letters: The Correspondence Between Sigmund Freud and C.G. Jung, Ralph Manheim and R.F.C. Hull (trans.) abridged by Alan McGlashan (London: Penguin, 1991), 125-6: 126; cf. Sulloway, op. cit. (note 5), 636-43; Volkmar Sigusch's paper in this issue.

165 Sigmund Freud, Letter 114F to Jung (12 November 1908), in McGuire (ed.), ibid., 127.

166 Moll, op. cit. (note 93), 54-5; Sigmund Freud, Letter 141F to Jung (16 May 1909), in McGuire (ed.), ibid., 147-8: 148.

${ }^{167}$ Freud, 'Drei Abhandlungen', op. cit. (note 6), 81-2 (note 2); Isidor Sadger, 'Sexualität und Erotik im Kindesalter. Eine psychoanalytische Studie', Moderne Medizin, 6 (1915), 11-17 and 21-7: 16.
} 
After the death in 1902 of Krafft-Ebing, Moll was amongst the best-known sexologists in Europe. ${ }^{168} \mathrm{He}$ was regarded as the authority on childhood sexuality and a recognised medical expert for sexual pathologies who was regularly called upon by courts to report as an expert witness (see Matthew Conn's paper in this issue). However, Moll's fame as a sexologist and psychologist soon began to wane and, from the 1920s/30s, he became increasingly marginalised, not only by Freud and the psychoanalytical movement, but also by Jung and psychologists such as Stern and Bühler, and those working in the new discipline of child and youth studies. ${ }^{169}$ Whereas Freud, Jung, Stern and Bühler established their own academic schools and reached out to a wider educated public through their lectures at universities - although Jung had given up his position at Zurich University in 1914 - Moll lacked such opportunities, not having an academic position. Although Moll had founded a society and was involved in the publication of a journal, this did not have as great an impact as the rising psychoanalytical movement and the appeal that Freud's widely interdisciplinary approach and thinking had for many intellectuals in the first half of the twentieth century. ${ }^{170}$

The critique of Moll by psychoanalysts quickly gained force. Already in 1908, the Viennese paediatrician and close friend of Freud, Oscar Rie (1863-1931), had criticised Moll for not doing justice to Freud's research, claiming that Moll had been inspired by Freud and even quietly accepted his results. ${ }^{171}$ Five years later, the Freudian psychoanalyst and co-founder of the American Psychoanalytic Association, Ernest Jones (1879-1958), writing upon the publication of the English translation of Moll's book in 1912, confirmed Freud's priority for the discovery of childhood sexuality. ${ }^{172}$ A reviewer in the flagship Journal of Nervous and Mental Diseases, despite praising Moll's book as of 'practical service', criticised him for not following Freud's theories. Had he done so, the reviewer argued, Moll would have achieved 'a more complete understanding of that comprehensive conception of sexuality in child life'. ${ }^{173}$ In an overview of childhood sexuality from 1923, the Viennese paediatrician Josef Friedjung (1871-1946), a former follower of Freud who subsequently sided with Alfred Adler, commented in friendly terms on Moll's book, calling it a 'valuable piece of work'. He concluded, however, that Moll had still been captured by 'prejudices and considerations which have nothing to do with the topic itself'. By and large, Friedjung then followed Freudian thinking and not Moll's. ${ }^{174}$

Besides these external factors, it is possible to detect some characteristics of Moll's writing that contributed to his eventual eclipse. Moll's writing style was not very accessible and his terminology at times opaque. For example, the two notions he coined to describe his libido theory, the detumescence- and contrectation-impulses, were not picked up by many other researchers at the time, one of the exceptions being Hans Blüher (1888-1955)

\footnotetext{
168 Oosterhuis, op. cit. (note 25), 279.

169 Sulloway, op. cit. (note 5), 415-6; Makari, op. cit. (note 148); Gebhardt, op. cit. (note 9), ch. 1; Dudek, op. cit. (note 154), chs 5 and 7; Bühring, op. cit. (note 154).

170 See, for instance, Makari, op. cit. (note 148); Gay, op. cit. (note 147).

171 Rie, op. cit. (note 128).

172 Ernest Jones, Journal of Philosophy, Psychology and Scientific Methods, 10 (1913), 188-90: 189; likewise Otto Rank (Internationale Zeitschrift für ärztliche Psychoanalyse, 2 (1914), 284-6: 285) in a review of Moll's Handbuch der Sexualwissenschaften, claiming that Moll discovered childhood sexuality four years after Freud.

173 L.B., op. cit. (note 108), 719.

174 Josef K. Friedjung, Die kindliche Sexualität und ihre Bedeutung für Erziehung und ärztliche Praxis (Berlin: Springer, 1923) (offprint from, Ergebnisse der inneren Medizin und Kinderheilkunde, Vol. 24), 5-6.
} 
in his work on homosexuality in the German youth movement. ${ }^{175}$ Furthermore, in contrast to Freud, Moll did not get straight to the point but usually took some time to develop his ideas and theories, often going back and forth in his arguments and repeating the same point again and again with only slight modifications, a habit that some contemporary reviewers criticised him for. ${ }^{176}$ His style of argument may have allowed Moll to develop a more nuanced and less dogmatic theory than Freud, but it could also have been perceived as indecisive and shying away from clear statements.

\section{Conclusion}

At the beginning of the twentieth century, children's sexuality was understood by many experts from different disciplines, including paediatrics, sexology, psychology, psychiatry, psychoanalysis and pedagogy, as part of a child's 'normal' development. The nineteenthcentury approach that had pathologised sexual feelings and activities of children - or, to be more precise, feelings and activities that were perceived as being of a sexual nature - had become obsolete. However, contrasting theories and explanations, as well as open questions, persisted. Freud and other psychoanalysts, for instance, continued to discuss the detrimental effects of masturbation for at least the following two decades, whereas Moll could not see such pathological effects. ${ }^{177}$

The central difference between the different concepts of childhood sexuality related to how children's sexual experiences were explained and understood. Moll and other researchers at the time (eg. Ellis) and later on (eg. Alfred Kinsey) likened children's sexual feelings and activities, implicitly and explicitly, to those of adults. Children's sexual experiences were understood by them to be of the same character as adults' sexual experiences, and children's sexual activities and feelings were interpreted as early forms of adults' sexual activities and feelings. Freud and other psychoanalysts, in contrast, argued that children's sexual feelings and experiences were of a different, polymorphic sensual nature, but they maintained that such feelings and experiences were still triggered by the same sexual libido as in adults. Hence, although in different ways, both Moll and Freud explained infant and child behaviour in terms of adult sexuality, but Freud's use of projections allowed for greater complexity in the argument. This homological interpretation of child sexuality was deeply embedded in the cultural thinking of the finde-siècle. Intellectuals, writers and artists were obsessed with a sexualised understanding of children, in particular of girls before puberty.

The position of C.G. Jung is ambiguous. He fundamentally disagreed with Freud's theory of infant sexuality and the libido theory, but there is no indication that Jung interpreted emerging sexuality in children as distinct from adult sexuality. Jung, Bühler and Stern distanced themselves from any form of projecting an adult understanding of sex onto children. Bühler, like Moll and Freud, saw expressions of sexuality in infants and

\footnotetext{
175 Hans Blüher, Die Wandervogelbewegung als erotisches Phänomen. Ein Beitrag zur Erkenntnis der sexuellen Inversion (Berlin: Weise, 1912), cf. Geuter, op. cit. (note 125), 84 and 276.

${ }^{176}$ Rie, op. cit. (note 128), 797; The Athenaeum, op. cit. (note 134). A reviewer for the American Journal of Psychology, op. cit. (note 128), even suggested an abridged version of Moll's book to be published with his conclusions and recommendations but without all the details.

${ }^{177}$ However, not all psychoanalysts agreed with Freud. Wilhelm Stekel, for instance, did not believe masturbation was pathological as such; rather, the pathological effect was caused by those fighting against masturbation. Nunberg and Federn (eds), op. cit. (note 164), Vol. 1, 1906-1908 (1976), 264-8; Vol. 2, 1908-1910 (1977), 502-28; Vol. 3, 1910-1911 (1979), 306-13, 321-30 and 339-47; Vol. 4, 1912-1918 (1981), 18-25, 32-9, 53-7, 63-76 and 86-90.
} 
children as normal. However, by contrast, Stern rejected any notion of a normal sexuality in children, and Jung perceived the first three to five years of infanthood as a non-sexual phase.

Child psychologist Charlotte Bühler differed fundamentally from her fellow psychologists and from psychoanalysts insofar as she framed children's experiences of sexuality as being of a different nature and valid in their own right. Bühler made it clear that an activity in an infant or child did not necessarily mean the same as that activity in an adult. Hence, Bühler was the only proponent of a heterological understanding of childhood sexuality. The vast majority of commentators in the nineteenth and early twentieth centuries followed a homologous approach that sexualised children's behaviour in an adult manner - and one can still trace some of this understanding of child sexuality in today's moral panic over the sexualisation of children. 